\title{
Hasan Basri Çantay'ın Mehmet Âkif Ersoy'la Dostluğu ve Millî Mücadele'ye Katkıları*
}

\section{Hasan Basri Çantay's Friendship with Mehmet Akif Ersoy and His Contributions to the National Struggle}

\author{
Dr. Öğr. Üyesi Zekiye SÖNMEZ ID1
}

\begin{abstract}
$\ddot{\mathbf{O z}}$
Hasan Basri Çantay, Balıkesir'in (Karesi) yetiştirdiği en büyük şahsiyetlerden biridir. Onun dindarlığı, mücadeleci bir ruh yapısına sahip olması, gazeteciliğgi, dostlarına olan vefası, vatan-millet sevgisi ve Millî Mücadele'ye katkı yapması gibi özellikleri büyük bir şahsiyet olmasında önemli etkenlerdendir. Aynı şekilde Hasan Basri'yi büyük yapan etkenlerden biri de İstiklâl Şairi Mehmet Âkif'le olan dostluğudur. Onların dostluklarının temelini din, vatan ve millet sevgisi oluşturmaktadır. Ayrıca her iki şahsiyetin birbirine bağlanmasında "Balıkesir Sevgisi" de önemlidir. Hasan Basri Çantay ve Mehmet Âkif'in bu değerler temelinde 1908 de başlayan dostlukları, Millî Mücadele dönemi boyunca devam etmiş ve İstiklâl Marşı'nın yazılması aşamasında taçlanmıştır. Hasan Basri, Ses ve diğer gazetelerdeki yazılarıyla başladığı Millî Mücadele çalışmalarını; İzmir, Balıkesir ve Sivas illerinde yapılan ulusal ve bölgesel nitelikli kongrelere katılma çabalarıyla sürdürmüştür. Daha sonra o, bizzat Birinci Türkiye Büyük Millet Meclisi'nde Balıkesir Milletvekili olarak vatanın ve milletin kurtuluşuyla ilgili çalışmalara etkin bir şekilde katılmıştır. Bu makalenin amacı: Balıkesir'in en önemli şahsiyetlerinden Hasan Basri Çantay ile Balıkesir sevdalısı Mehmet Âkif Ersoy'un dostluklarını ve Hasan Basri’nin Millî Mücadele Dönemi'ndeki çalışmalarını bir nebze de olsa değinebilmek ve onların unutulmamalarını sağlamaktır.
\end{abstract}

Anahtar Kelimeler: Hasan Basri Çantay, Balıkesir (Karesi), Mehmet Âkif Ersoy, millî mücadele, dostluk

Makale Türü: Derleme

\begin{abstract}
Hasan Basri Çantay is one of the greatest people of Balıkesir (Karesi). His features such as piety, fighting spirit, journalism, loyalty to his friends, love of the homeland and the nation and contributions to the National Struggle are the important factors in his being a great person. At the same time, his friendship with Mehmet Akif who is the poet of independence is another factor which made him a great person. The basis of their friendship consists of the love of the religion, homeland and nation. Besides, "the love of Balıkesir" is also important in bringing them together. Hasan Basri Çantay and Mehmet Akif's friendship which started in 1908, on the basis of these values, continued throughout the period of the National Struggle and reached its peak in the process of writing the National Anthem. Hasan Basri continued his National Struggle works which started with his writings in Ses and the other newspapers, with his efforts to participate in the national and regional congresses in İzmir, Balıkesir and Sivas. Later, he took an active role in the liberation of the homeland and the nation as the deputy of Balıkesir in the 1st Grand National Assembly of Turkey. The purpose of this paper to touch on the friendship of Hasan Basri Çantay

${ }^{*}$ Bu çalışmanın ilk hali 19-21 Eylül 2014 tarihlerinde Balıkesir’de düzenlenen Vefatının 50. Yılında Hasan Basri Çantay Sempozyumu'nda sözlü bildiri olarak sunulmuştur.

${ }^{1}$ Afyon Kocatepe Üniversitesi, İslami İlimler Fakültesi, zsonmez@aku.edu.tr.
\end{abstract}

Atıf için (to cite): Sönmez, Z. (2020). Hasan Basri Çantay'ın Mehmet Âkif Ersoy'la dostluğu ve Millî Mücadele'ye katkıları. Afyon Kocatepe Üniversitesi Sosyal Bilimler Dergisi, 22(TBMM'nin 100. Yılı ve Millî İrade Özel Sayısı), 172-189. 
who is one of the most important people of Balıkesir and Mehmet Akif Ersoy who is the Balıkesir lover and the works of Hasan Basri during the National Struggle Period and to ensure them not forgotten.

Keywords: Hasan Basri Çantay, Balıkesir (Karesi), Mehmet Akif Ersoy, national struggle, friendship

Paper Type: Review

\section{Giriş}

Merhum Hasan Basri Çantay (1887-1964)2, Balıkesir'in (Karesi) $)^{3}$ yetiştirdiği; İslâmî ilimlere vakıf, âlim, şair, yazar, hukukçu, iktisatçı ve musikiyle ilgisi olan çok yönlü özelliklere sahip bir şahsiyettir. Günümüz tarihçilerinden Kadir Misıroğlu'na göre; Hasan Basri ilmiye sınıfından olmadığı halde ulemanın bütün vasıflarına sahip, hatta Millî Mücadele Dönemi’nde ilmiyeli olanlardan çok daha fazla dinî heyecanı harekete geçiren hizmetler ifa etmiştir (Misıroğlu, 1967, s. 241). Bütün bu özelliklerden onun; çalışkan, kararlı ve mücadeleci bir ruh yapısına sahip olduğu anlaşılmaktadır. Ayrıca onun kendi ruh yapısına sahip insanlarla olan dostluğu ve dostlarına olan vefâsı da anılmaya değerdir.

Hasan Basri Çantay’ın, Mehmet Âkif Ersoy'la dostluğu ve dostlarına verdiği önemle ilgili olarak dost ve dostluk kelimeleri üzerinde durmak gerekir. Türkçeye Farsçadan geçmiş olan "dost" kelimesinin sözlükte; sevilen kimse, sevgili, arkadaş, aralarında iyi ilişkiler olan, bir şeye düşkünlük gösteren, gerçek sevgili olan Allah... gibi birçok anlamı vardır. Ayrıca "dostluk" ise 'dost olma hali' olarak tanımlanmaktadır (Doğan, 1992, s. 277). Sözlük anlamının yanı sıra dostluk kavramı; tanımlaması zor, kültürden kültüre ve devirden devire değişebilecek bir anlam ifade etmektedir. Bu bağlamda dostluk; sosyal bir varlık olarak insanın, kardeşlik, akrabalık ve arkadaşlık gibi farklı boyutlarda geliştirdiği birçok ilişki boyutundan birisi ve hemen her kültürde var olan insani gerçekliktir. Bundan dolayi tarih boyunca Sokrates, Aristoteles, Cicero ve Mevlâna gibi birçok düşünür bu konuyla ilgilenmiş ve dostluğun insanın bireysel ve toplumsal hayatı için önemi üzerinde durmuştur. Onlar, dostluğun insan için vazgeçilmez bir şey olduğunu, fedakârlık ve sürdürebilirlik gerektirdiğini vurgulamıştır. ${ }^{4} \mathrm{Bu}$ manada dostluk hem kişinin ruh sağlığı hem karşılıklı fedakârlık ve sürdürebilirlik gerektirdiği için toplumda birliğin, beraberliğin ve bütünlüğün sağlanmasında önemli bir ilişki türü olarak kabul edilmiştir. Bununla birlikte dostluk kurulacak kimselerin seçiminde ise Kur'an'daki birçok ayette "inanç birliğini”" esas almış ve inananların/mü'minlerin ancak birbirleriyle dost olabileceği (Âl-i İmrân, 3: 28, 118; Nisâ, 4: 139; Tevbe, 9:16; Mümtehine, 60:1,13) vurgulanmıștır. Ayrıca Kur'an, toplum düzeninin sağlanmasında, düşmanca davranıșlar içinde bulunan ve inanmayanların 1slahı bağlamında "İyilikle kötülük bir olmaz. Sen kötülüğü en güzel şekilde önle. O zaman göreceksin ki, aranızda düşmanlık bulunan kişi sanki candan, sımsıcak bir dost oluvermiştir" (Fussilet, 41,34) diyerek onlarla da iyi geçinilmesi gerektiğini belirtmiştir.

\footnotetext{
${ }^{2}$ Hasan Basri Çantay, Balıkesir'de tüccar ve ulema Çantayoğlu Halil Cenabi Efendi ile Sincanoğullarından Kepsutlu Hatice Hanım'ın çocukları olarak 1887 'de dünyaya geldi. Çantayzâdeler olarak bilinen ailenin tek erkek çocuğu olan Hasan Basri ilk öğretimini İbtida -i Kebir Mektebi'nde gördükten sonra Balıkesir İdâdîsine (lise) girdi. Hasan Basri'nin on altı yaşındayken (1903) babasını kaybetmesi, eğitim öğretiminin yarıda kesilmesine ve ailenin geçimi için çalışmak zorunda kalmasına sebep oldu. Fakat onun zekasını, çalışma azmini, şiirdeki marifetini ve kararlılı̆̆ını fark eden, Balıkesir Mutasarrıfları (Mutasarrıf, Tanzimat'tan sonra bir sancağın (liva) en büyük mülkî amirine verilen unvandır.) Ömer Ali Bey ve Mehmet Ali Aynî Beylerin desteğiyle hem çalıșma hem de eğitim öğretim hayatını sürdürme firsatı buldu. Ayrıca o; din, edebiyat, felsefe, hukuk ve iktisat gibi birçok alanda önde gelen şahsiyetlerden dersler aldı (Iş̧ı, 1993, s. 218; Uğur, 1994, s. 1-6).

${ }^{3}$ Bugünkü Balıkesir (Karesi), bir zamanlar Küçük Asya'nın Mizi (Mizya-Mysia) ismi verilen kısmındaydı. Mizya'ya Canakkale, Bergama ve Hüdavendigâr Vilayetleri de dahildi (Uzunçarşıll, 2000, s. 3-4); Bazı kaynaklar; "İslâm memleketlerinden ilk önce Osmanlılı̆̆ iltihak eden (katılan) yerin Karesi Eyaleti olduğunu ve onun katılmasından sonra Osmanlıların asıl șevket, kudret ve başarıyı elde ettiklerini" belirtmektedir (Uğur, 1994, s. 199); Osmanlılar zamanında Karesi, Anadolu Beylerbeyliği'nin (Eyâleti'nin) Paşa Sancağı olan Kütahya'ya bağlı bir sancaktı. O zamanlar Karesi Sancağı, aşağı yukarı bugünkü Balıkesir'in topraklarıyla, doğusundaki bir kısım yerleri kapsamaktaydı (Akarslan, 1998, s. 21).

${ }^{4}$ Tarih boyunca birçok düşünür dostluğun öneminden bahsetmiştir. Bunlar arasında Sokrates (M.Ö.469-399), Aristoteles (M.Ö.384322), Cicero ve Mevlâna gibi düşünürler vardır. Bu düşünürlerin, özellikle Cicero ve Mevlâna'nın dostluk hakkındaki görüşleri için bk. (Çiçek, 2017: s. 1-7).
} 
Kur'an'ın ifadesine benzer şekilde Hz. Muhammed de "Kişi dostunun dini üzeredir. Öyleyse her biriniz, kiminle dostluk kuracağına dikkat etsin" (Ebu Davud, Edeb, 19, Hadis No, 4843) diyerek, dost seçerken dikkatli olunması gerektiğini vurgulamıştır.

Dost seçmek kadar, dostluğa değer vermek ve dostunu hatırlamak, yerine göre dostunu arayıp halini hatırını sormak ve zor günlerinde onun yanında olmak da önemlidir. Bu çerçevede Kur'an'da Allah (c.c) "Anın beni anayım sizi!" (Bakara, 2, 152) buyurmaktadır. Aynı şekilde bir yazar da "Anmak, dünü bugüne taşımak, bugünü yarına bağlamaktır. Anmak vefakârlık; anılmak unutulmamaktır. Anmak dirilmek, anılmak canlılıktır. Halk diliyle anılmak; adın batmaması, ocağın sönmemesi, defterin dürülmemesidir. Bu anlamda anmak da anılmak da güzeldir, nimettir ve meziyettir." demektedir (Çakan, 2006, s. 13). Anılmak ve unutulmamakla ilgili olarak Hasan Basri, dostu Mehmet Akif'e atfettiği eseri "Âkifnâme"nin önsözünde şöyle güzel bir ifadeye yer vermektedir: "Merhum Süleyman Nazif'in hayattayken en çok üzüldüğü şey, adının unutulmasıydı. Sövmek bile ona hoş gelirdi. Çünkü ancak o sayede yaşadığını anlayabilirdi..." Ayrıca o, Avni'den bir alıntıyla 'Bin safsata bir mısra1 bercesteye değmez.' demektedir (Çantay, 1966, s. 12). Hasan Basri her ne kadar bu sözleri Süleyman Nazif ve Mehmet Âkif için ifade etmeye çalışmış ise de kendisinin de unutulup gitmeyi istemediğini anlayabiliriz. Aynı şekilde Mehmet Âkif de "Son Nefesimle Hasbihâl" adlı şiirinde "Evlâdımı, ecdâdıma bîgane görürsem; Ruhum ebediyyette kalır, ebkemü mâtem." diyerek, gelecek nesillerin atalarını unutmaları halinde, onların ruhlarının sonsuza kadar mâtem içinde olacağını belirtmektedir (Çantay, 1966, s. 205). Hasan Basri, Mehmet Âkif'in bu hislerine bigâne kalmamıştır. O, hayatı ve eserleriyle büyük bir tarih olan Mehmet Âkif'i ve ondaki dinî ve millî şuuru gelecek nesillere tanıtmaya çalışarak görevini yapmıştır.

Dolayısıyla bu çalışmada: Hasan Basri Çantay ve Mehmet Âkif Ersoy'un din, vatan ve millet sevgisine dayalı dostlukları; bu dostluğun Millî Mücâdele döneminde farklı alanlarda ortaya çıkması ve topluma yansımaları; ayrıca Hasan Basri'nin Millî Mücadele sırasındaki faaliyetleri konu edilecektir. Bu çerçevede çalışmamız, Hasan Basri Çantay'ın Mehmet Âkif Ersoy'la dostluğu ve Hasan Basri Çantay'ın Millî Mücadele'ye katkıları olmak üzere iki ana bölüm ve alt bölümlerden oluşmaktadır.

\section{Hasan Basri Çantay'ın Mehmet Âkif Ersoy'la Dostluğu}

Arkadaşlık ve dostluk konusunda "Bana dostunu söyle, sana kim olduğunu söyleyeyim." şeklindeki atasözümüz, Hasan Basri ve İstiklâl Şairimiz Mehmet Âkif'in dostluklarını en iyi şekilde anlatmaktadır. Hasan Basri'nin Mehmet Âkif Ersoy'la olan dostluğu 1908 yılında İstanbul'da, Strat-ı Mustakim dergisinin idare merkezinde tanışmalarıyla başlamıştır (Çantay, 1966, s. 25). Onların dostlukları, Hasan Basri'nin çeşitli vesilelerle İstanbul'a gitmesi ve orada görüşmeleriyle devam etmiştir. Ayrıca Mehmet Âkif'in, Eşref Edip'in yazılarının Ses Gazetesi'nde yayınlanması için Balıkesir'e ulaştırılması görevini üstlenmesi de dostluklarının güçlenmesinde önemli olmuştur (Çantay, 1966, s. 25). Bunlarla birlikte her iki şahsiyetin Millî Mücadele sırasında din, vatan ve millet sevgisi çerçevesinde Balıkesir ve Ankara'da bir araya gelmeleri dostluklarını kalıcı kılmıştır.

\subsection{Din, Vatan, Millet ve Balıkesir Sevgisine Dayalı Dostluk}

Mehmet Âkifle Hasan Basri'nin dostluklarının temelinde din, vatan ve millet sevgisi vardır. Bu bağlamda Millî Mücadele döneminde, Hasan Basri Çantay'la Mehmet Âkif'in ilk olarak bir araya gelmeleri Balıkesir'de gerçekleşmiştir. Mehmet Âkif, memleketin içine düştüğü felaketler karşısında ruhunda firtınalar esmiş, sürekli bir mâtem ve feryat içinde olmuştur. Dahası memleket sevgisi ve istiklâl aşkı onun bütün varlığını kaplamıştır (Edip, 1938, s. 32). Ona göre; "... Dört sene cepheden cepheye koşarak memleketi savunan Âsım'ın nesli, nasıl olur da vatanın istilâ altında kalmasına razı olurdu? Fakat, Âsım'ın nesli bu hâle gelen memleketi nasıl koruyacaktı?" Âkif, bu sorunun cevabını düşünürken, kısa süre sonra Yunanlılar Balıkesir yöresine doğru ilerlemeye başlamışlardı. Âkif bu haberi duyar duymaz, Anadolu'ya "top ve 
tüfeğin patladığı yere" gitmek gerektiğini anlamış ve hemen Balıkesir'e gelmiştir (Erişirgil, 1986, s. 335).

Balıkesir'e geldiğinde topraklarını korumaya kararlı bir halk bulan Mehmet Âkif, 6 Şubat $1920{ }^{\prime} \mathrm{de}^{5}$ Zağnos Paşa Camii'nde halka hitaben etkili bir konuşma yapmıştır. O, bu konuşmasından önce Âl-i İmrân Sûresinin 100-104. ayetlerini, arkasından da o sıralarda yeni yazmış olduğu "Alınlar Terlemeli" başlık manzumesini okumuştur. Bu konuşma Balıkesirlileri oldukça etkilemiş ve onların vatan ve millet sevgisini perçinlemiştir (Erişirgil,1986, s. 335; İmamoğlu, 2008, s. 178-180). Mehmet Âkif Balıkesir'de bulunduğu sıralarda Hasan Basri onu evinde misafir etmiş (Erişirgil,1986, s. 335) ve böylece dostlukları kuvvetlenmiştir (Çevik, 2009, s. 857-858).

Hasan Basri'nin ifadesine göre Mehmet Âkif, Balıkesir ve Balıkesirlileri çok sevmiş, hatta o ömrünün sonuna kadar hep Balıkesir'e yerleşme ümidiyle yaşamıştır. ${ }^{6}$ Hatta Mehmet Âkif, Ankara'da Tâceddin Dergahı'nda bulunduğu sırada Balıkesir'in Yunanlılar tarafından işgal edildiği haberi üzerine "Ey Benim her taşı bir mabed-i iman yurdum; Seni er geç bana mutlak verecek mabudum." diyerek bu ümidini dile getirmiştir (Kutay, ty, s. 11073). Dolayısıyla Balıkesir, bu iki büyük şahsiyetin dostluklarında önemli bir rol oynamıştır.

$\mathrm{Bu}$ iki büyük insanın dostluklarını ifade ederken "Dost dostun aynasıdır" özdeyişini kullanmak yerinde olacaktır. Çünkü onların dostluklarının güçlenmesinde, iki şahsiyetin benzer özelliklere sahip olması etkili olmuştur. Bu bağlamda Hasan Basri, Mehmet Âkif'i "Riyasız bir vatanperver ve kâmil bir mü'mindir. Onun en büyük düşmanı riyakârlıktır. Din namına yapılan maskaralıklara asla müsaade etmez. Hayatı boyunca gericilikle, cehâletle, bâtıl inançlarla, miskinlikle mücadele etmiştir. Vefa en bariz vasfıdır. Diğergamdır. Alçakgönüllüdür. Sadeliği sever. Bir çocuk gibi saf ve masumdur; hemen her söylenene inanır. Zalime düşmandır. Haksızlığa tahammül edemez. Hayatı boyunca başını öne eğdiği görülmemiştir..." şeklinde vasıflandırmıştır (Karataş, 2009, s. 189; Edip, 1938, s. 249-280). Bu vasıflar yanında Hasan Basri onun için "Ooo...Adamdır, adam" demiştir (Karataş, 2009, s. 188). Aynı şekilde, hayat tarzından, gazetelerdeki yazılarından ve Millî Mücadele'deki duruşundan anladığımız kadarıyla Mehmet Âkif'in vasıflarının aynısı Hasan Basri'de de vardır. Bu çerçevede Mehmet Âkif Hasan Basri'yi "... O, ne arkadaş canlısı bir efendidir. Şiir zevki tamam, ilim zevki tamam, her şeyi tamam... Onu altınla tartmak mümkün değil, elmasla belki... Lâkin o kadar büyük elmas dünyada var mı?..." diyerek, övgüde bulunmuştur (Çantay, 1966, s. 260).

\section{2. İstikıâl Marşı'nın Yazılması ve Tamamlanması Sürecinde Dostluk}

Hasan Basri ile Mehmet Âkif'in dostluklarının en güçlü olduğu anlar Ankara'da Taceddin Dergâhı'nda bulundukları sırada, özellikle de İstiklâl Marşı'nın yazılması aşamasında olmuştur. Bu aşama Maârif Vekâletinin (Millî Eğitim Bakanlığının) Millî İstiklâlimizi en güzel şekilde ifade eden bir marşın yazılmasıyla ilgili bir yarışma ilanıyla başlamıştır. Böyle bir ilan neticesinde 724 şiir Millî Eğitime gelmiş, fakat bu şiirlerin büyük çoğunluğunun aranan özellikleri taşıyacak nitelikte olmadığ görülmüştür (Edip, 1938, s. 72). O günün Millî Eğitim Bakanı Hamdullah Suphi Bey, böyle bir şiiri Mehmet Âkifin yazabileceğine kanaat getirmiş ve ona durum bildirilmiştir. Ancak Mehmet Âkif, kesinlikle böyle yarışmaya girmeyeceğini ve ödül de almayacağını belirtmiştir. Bunun üzerine Hamdullah Suphi Bey, Mehmet Âkif'i ikna etmesi için Hasan Basri'ye ricada bulunmuştur. Hasan Basri, Mehmet Âkifin ödülden rahatsız olduğu için yazmadığını, eğer buna bir çare bulunursa, onu ikna edebileceğini bildirmiştir. Bunu duyan Hamdullah Suphi, onun hassasiyetlerinin dikkate alınacağını ifade eden bir tezkireyi Hasan Basri'ye vermiştir. Hasan Basri, tezkireyi Mehmet Âkife hemen vermemiş; Meclis'te otururlarken, onun kafasındaki şüpheleri yok eden konuşmalar yapmış ve onu İstiklâl Marşı'nı

\footnotetext{
${ }^{5}$ Bir kısım kaynaklar Mehmet Âkif'in Balıkesir'e gelişini ve halka vaaz verdiği tarihi farklı bir şekilde göstermektedir. Buna göre, Mehmet Âkif'in Zağnos Paşa Camii'nde 23 Ocak 1920 Cuma Namazından sonra halka vaaz verdiğinden hareketle, Balıkesir'e 21 veya 22 Ocak 1920'de gelmiş olabileceği belirtilmektedir (İlgürel, 1999, s. 22).

6(Çantay, 1966, s. 24); Mehmet Âkif, özellikle Burhaniye'nin Pelit köyüne yerleşmek istemiştir (Çantay, 1966, s. 260).
} 
yazmayı ikna etmiştir. Mehmet Âkif ikna olduktan hemen sonra, Meclis'te otururken şiiri yazmaya başlamıştır (Çantay, 1966, s. 62-64; Şen, ty, s. 66-68).

Mehmet Âkif'in İstiklâl Marşı'nı yazması Taceddin Dergâhı'nda ${ }^{7}$ devam etmiştir. O, şiiri yazarken çok yoğun zihnî tefekkür içinde olmuştur. Hatta ona ilhamın geldiği ve kâğıt bulamadığı anlarda, şiiri Taceddin Dergâh'ındaki odasının duvarlarına yazmıştır. Mehmet Âkif, iki gün süren böyle bir yoğun zihnî süreçten sonra İstiklâl Marşı'nı yazmıştır (Edip, 1938, s. 7071; Şen, s. 68-69).

İstiklâl Marşı yazılmıştı, ancak henüz Birinci Türkiye Büyük Millet Meclisi'nde kabul edilmemişti. Onun kabulü için 12 Mart 1337 (1921) tarihinde Meclis'e İstiklâl Marşı Kanun Tasarısı gündeme getirilmiştir. Bununla ilgili olarak Balıkesir Milletvekili Hasan Basri ve altı milletvekili arkadaş $1^{8}$ Mehmet Âkif'in şiirinin kabulünü teklif eden bir önerge hazırlamış ve meclis başkanı bu önergeyi oylamaya koymuştur (Edip, 1938, s. 80-82; Şen, s. 68-69). O gün yapılan uzun müzakerelerden ${ }^{9}$ sonra Mehmet Âkif'in yazmış olduğu İstiklâl Marşı kabul edilmiştir. O kabul edildikten sonra, Maarif Vekili Hamdullah Suphi ${ }^{10}$ İstiklâl Marşı'nı tekrar kürsüde okumuş, millet vekilleri ayakta onu hem dinlemiş hem de alkışlamışlardır. Mehmet Âkif ise, müzakerelerin başladığı sırada sıkılarak salondan çıkmış, şiir için konulan ödülü de kesinlikle almamış ve onu bir hayır kurumuna tahsis etmiştir (Edip, 1938, s. 81-83; Çantay, 1966, s. 64-73).

\section{3. İstiklal Marşı’nın Kabulünden Sonraki Süreçte Dostluk}

İstiklan Marşı'nın kabülünden sonra da Hasan Basri ve Mehmet Âkif arasındaki dostluk ve dostluğun göstergesi olan vefakârlık devam etmiştir. Bu çerçevede onların dostluklarının pekiştiği anlardan birisi de Sakarya Savaşı'nın en sıkıntılı günlerinde, düşmanın top seslerinin Ankara'dan duyulduğu ve herkesin buradan uzaklaşmak için tetikte beklediği sıralarda olmuştur (Edip, 1938, s. 96-97). Bu sırada Millet Meclisi'nin Kayseri'ye nakli için hükümetin hazırlık yaptığı șeklindeki haberler üzerine on dokuzu ulemadan otuz dört milletvekili Taceddin Dergâhı'nın yanındaki evde sabahlamışlardır. Buradaki gizli celsede, Mehmet Âkif'in kararıyla ve Hasan Basri'nin kalemiyle "Eşiğinde ölür, amma binadan diri çıkıp bir adım geri gitmeyiz." şeklinde bir rapor hazırlanmıştır (Kutay, 1972, s. 256).

Dostluk karşıllklı fedakârlık ve vefakârlık gerektirir. Bu çerçevede Hasan Basri ve Mehmet Âkif, dostluklarını ve vefalarını kalemleriyle de birbirlerine göstermişlerdir. Bu bağlamda Mehmet Âkif, Yunanlıların Batı Anadolu'yu işgal ettiği sıralarda, özellikle Bursa ve Balıkesir'den kötü haberler gelmesi üzerine çok üzülmüş ve üzüntüsünü "Bülbül" şiirinde dile getirmiştir. $\mathrm{O}$, yazdığ 1 bu şiiri, Hasan Basri'nin beğenip, beğenmediğini sormuş ve onun beğendiğini söylemesi üzerine ona olan dostluğunun nişanesi olarak, kendisine ithaf ettiğini söylemiştir (Çantay, 1966, s. 207-208; Edip, 1938, s. 83-84). Mehmet Âkif "Basri Bey Ŏglumuza!" diyerek ithaf ettiği bu manzumeyle, dostu Hasan Basri'ye vefasını göstermiştir. Ali Rifat Bey tarafından bestelemiş olan bu manzumeyi Mehmet Âkif dinlemekten çok hoşlanmıştır (Erişirgil, 1986, s. 355; Edip, 1938, s. 92). Aynı şekilde Hasan Basri de 1918'de Mehmet Âkif'e "Sana Şair Diyemem" başlıklı bir şiir yazmıştır (Çantay, 1966, s. 227). Ayrıca Mahir İz'in deyimiyle Üstad Hasan Basri Çantay, dostu Mehmet Âkife olan vefasını, "Âkifnâme"yi tarihe hediye ederek göstermiştir (Çantay, 1966, s. 6). Dolayısıyla her iki büyük insanın dostluğun gereği olan vefayı önemsedikleri anlaşılmaktadır.

\footnotetext{
7 Tâceddin Dergâhı, Ankara Tekke Ahmed Mahallesinde (Bugün Ankara'nın Altındağ ilçesi sınırları içinde Hacettepe Hastanesi yanında) Şeyh Paşa Zaviyesi derununda Aziz Mahmud Hüdâyî (950/1543-1038/1628) halifelerinden es-Seyyid eş-Şeyh Tâceddin Mustafa el-Ankaravî tarafından XVII. yüzyılın ilk yarısında külliye halinde yaptırılmış ve vakfedilmiştir... (Öztürk, 2009, s. 240).

${ }^{8}$ Mehmet Âkif'in yazdığı İstiklâl Marşı'nın kabulü için Meclis'e önerge veren Balıkesir Mebusu Hasan Basri'nin diğer arkadaşları şunlardır: Kastamonu Mebusu Dr. Suat, Ankara Mebusu Şemseddin, Bursa Mebusu Emin, Bitlis Mebusu Yusuf Ziya, Isparta Mebusu İbrahim, Kırşehir Mebusu Yahya Galip'dir (Goloğlu, 1971, s. 121).

9 İstiklâl Marşı'nın kabulü sırasında Meclis'teki müzakerelerle ilgili bk. (Goloğlu, 1971, s. 113-121).

10 İstiklâl Marşı'nın Meclis'te kabul edilmesinde en büyük rolün, o sırada Millî Eğitim Bakanı olan Hamdullah Suphi Bey'e ait olduğu belirtilmiştir (Ağaoğlu, 1944, s. 257).
} 


\section{Hasan Basri Çantay'ın Millî Mücadele'ye Katkıları}

Hasan Basri Çantay, Mehmet Âkif’e karşı dostluğunu ve vefasını gösterdiği gibi; dinine, vatanına ve milletine olan dostluğunu ve vefasını da yine farklı biçimlerde ortaya koymaya çalışmıştır. Onun Milli Mücadele'ye katkı yapmasında, daha lise yıllarından itibaren din, dil, edebiyat, felsefe, hukuk ve iktisat gibi birçok alanda ileri gelen âlimlerden aldığ derslerin önemi büyüktür. Nitekim Hasan Basri’nin aldığı bu dersler, onun kalbinde din, devlet ve millet sevgisi gibi duyguların oluşmasında ve güçlenmesinde etkili olmuştur. Dolayısıyla onun bu duyguları, altı yüzyıllık Osmanlı Devleti'nin, Birinci Dünya Savaşı'nda yenilmesinden sonra, o günün Büyük Devletlerinin Osmanlı topraklarını aralarında paylaşmak için gizli planlarını bir dizi antlaşmayla ortaya koymaya çalıştığı ve memleketin durumunun kötüye gitmeye başladığ sırada daha da güçlenmiştir.

Onun bu konudaki katkılarına geçmeden önce, Millî Mücadele öncesi Anadolu'nun içinde bulunduğu siyasî durumdan kısaca bahsetmek yerinde olacaktır. Çünkü Millî Mücadele dönemini anlayabilmek için, bu dönemin öncesinde meydana gelen olayları iyi bilmek gerekmektedir.

\subsection{Millî Mücadele Öncesi Anadolu'da Durum}

Millî Mücadele'nin başlamasına, Osmanlı Devleti’nin yirminci yüzyılın başlarından itibaren içerde ve dışarıda yaşadığı çeşitli sıkıntılar sebep oldu. Osmanlı Devleti'nin sıkıntılarının giderilmesine ve Devlet'in güçlenmesine; Osmanlı toplumunun yenileşmesine ve çağdaşlaşmasına vesile olmak üzere 23 (24) Temmuz 1908'de II. Meşrutiyet ilan edildi. Fakat II. Meşrutiyet'in ilanı devletin sıkıntılarını gidermediği gibi, aksine onun yıkılmasına zemin hazırladı 1909 tarihinde İttihat ve Terakkî Cemiyeti'nin iktidarı ele geçirmesi ve muhalefeti sindirerek keyfi uygulamalar yapması ülke çapında iç ayaklanmaların başlamasına sebep oldu. ${ }^{11}$ Bunun yanı sıra Osmanlı Devleti, 1911-1912 yıllarında İtalya'yla Trablusgarp Savaşı'nı yaptı. Arkasından 1912-1913 y1llarında Sırbistan, Karadağ, Bulgaristan, Yunanistan ile Balkan Savaşlarını ${ }^{12}$ yaptı. ${ }^{13}$ Bu savaşlardan sonra Osmanlı Devleti, 1914'te üç kit'a ve sekiz cephede iki buçuk milyondan fazla askerle Birinci Dünya Savaşı'na katıldı. Yaklaşık dört y1l (28 Temmuz1914-11 Kasım1918) süren bu savaş, her alanda Osmanlı'yı gerçekten yıprattı. Savaşın gidişatından Osmanlı Devleti'nin yenileceğini gören İngiltere, Fransa, Rusya ve İtalya gibi büyük devletler zaman zaman bir araya gelip gizli antlaşmalarla Osmanlı topraklarını kendi aralarında paylaşmaya başladı (Aydınel, 1973, s. 5-6). Öngörüldüğü gibi sonunda Osmanlı Devleti bu savaşta yenildi.

Altı yüzyıl kadar hüküm süren Osmanlı Devleti'nin girmek zorunda kaldığı Birinci Dünya Savaşı'nda yenilmesi, Türk Tarihi açısından önemli bir dönüm noktası teşkil etmiştir. Zira bu yenilgiyle birlikte başta Wilson İlkeleri ${ }^{14}$, Mondros Mütarekesi (Ateşkes Antlaşması) ${ }^{15}$, Paris Barış Konferans $1^{16}$ ve Sevr Barış Antlaşmas $1^{17}$ gibi bir dizi antlaşma Osmanlı'nın yıkılış sürecinde birer adım oluşturmuştur.

\footnotetext{
${ }^{11}$ II. Meşrutiyet'in ilanına müteakip Osmanlı'da yaşananlarla ilgili geniş bilgi için bk. (Parlak, 1982, s. 11-58).

12 İstiklâl Şairimiz Mehmet Âkif, Balkan Savaşı'ndan sonra memleketin içine düştüğü durumu Sebilürreşad'da yazdığı bir makalesinde "Dökülen kanlar, yakılan canlar, söndürülen hânümanlar, kül olan sâmânlar, pâyimâl edilen ırzlar, ayaklar altında kalan nâmuslar, düşman ayağıyla çiğnenen yurdlar, sefâletlerin en müthişi içinde ölümünü bekleyen dullar, yetimler, kadınlar o kadar çok, o kadar çok ki, hepsini şöyle dursun, binde birini düşünebilecek beyin için, çıldırmamak kaabil değil..." diyerek dile getirmiştir (Edip, 1938, s. 33).

13 Balkan Savaşları hakkında detaylı bilgi için bk. (Alpaslan, 2013).

14 Wilson İlkeleri, Birinci Dünya Savaşı devam ederken Amerika Birleşik Devletleri Başkanı Woodrow Wilson'un 8 Ocak 1918 'de açıkladığı 14 maddelik barış ilkeleridir (Albayrak, 1998, s. 2).

1530 Ekim 1918 tarihinde, Ege Denizi'ndeki Limni Adası'nın güney kıyısındaki Mondros Limanı'nda demirli bulunan Agamemnon zırhlısında, Bahriye Nazırı Hüseyin Rauf Orbay'ın başkanlığını yaptığı Osmanlı Heyeti ile İngiliz hükümetinin müttefikleriyle yetkili kıldığı Amiral Calthorpe'nin başkanı olduğu İtilaf Devletleri Heyeti arasında 25 maddelik Mondros Mütarekesi imzalandı (Demirel, 2010, s. 11). Mütareke öncesi ve mütareke sürecindeki genel durum hakkında geniş bilgi için bk. (Tansel, 1973, s. 9-38).

${ }^{16}$ Mondros Mütarekesi'nden sonra, başta Amerika, İngiltere, Fransa, İtalya ve Japonya gibi büyük devletler olmak üzere 32 devletin temsilcilerinin katıldığı Paris Barış Konferansı 18 Ocak 1919'da tarihinde açıldı. Konferansın sözde amacı barışın gerçekleştirilmesi ve devamının sağlanmasıydı. Fakat bu amacın aksine, konferansın toplantılarında Wilson Prensipleri ve Mondros Mütarekesi'nin
} 
Osmanlı'nın yıkılış sürecinde Mondros Mütarekesi, Büyük Devletlerle Osmanlı Devleti arasındaki dünya savaşına kâğıt üzerinde son vermişti (Akyüz, 1975, s. 39). Fakat asıl savaş bundan sonra başlayacaktı. Çünkü Büyük Devletler, Mütarekenin maddeleri gereğince gizli planlarını uygulamaya koyacaklardı. ${ }^{18}$ Onların gizli planlarına göre, Osmanlı topraklarından kendi paylarına düşen kısmın dışındaki yerlerde; Rumlar Pontus Krallığını diriltecek, Ermeniler Erivan-Gümrü dolaylarında toplanan Taşnak Ordusunu Sivas'a kadar yürüterek Ermenistan'1 kuracaklardı. Yunan ordusu İzmir'i işgal edecek, Anadolu'da henüz silahlarını bırakmayan bazı Türk Kolordularını üzerlerine çekerek Kafkasya'da beliren ve Orta Doğu için tehlikeli görülen Bolşevik akınını önlemeye çalışan İngilizlere birer yardımcı tampon hazırlayacaklardı. Bu planı Halep, Musul, Kafkasya'daki İngiliz tümenleri destekleyecekti (Peker, 1955, s. 13).

Birinci Dünya Savaşı'nın akabinde, yukarıda sözü edilen kötü planlarını gizleyen Büyük Devletler, başta Wilson İlkeleri'nin 12. maddesi $^{19}$ ve diğer antlaşmalara göre Osmanlı'da bulunan azınlıkların haklarını savunacaklardı. Nitekim onlar, söz konusu antlaşmalarla Osmanlı topraklarında yaşayan azınlıkları çoğunluk konumuna çıkarmış; Türkleri ise Zeybek, Tatar, Yörük, Derviş, Bosnalı vs. şeklinde gruplara ayırmak suretiyle azınlık konumuna indirgemişlerdi. Böylece onlar, Türklerin azınlıkta olduğu yerleri işgal etmenin haklı gerekçesini hazırlamışlardı. Onlar, kendilerince haklı gibi görülen gerekçelerini desteklemek için Batı Anadolu'da yaşayan Rumlarda olduğu gibi ${ }^{20}$ Anadolu'nun değişik bölgelerinde bulunan azınlıklar için abartılmış nüfus istatistikleri ortaya atmışlardı. Bunun yanı sıra bu devletler, daha da ileri giderek Osmanlı toprakları üzerinde pazarlıklar yapmaya başlamışlardı (Albayrak, 1998, $1-12$; s. 16). Dolayısıyla söz konusu dönem, Osmanlı'nın topraklarının pazarlandığı, vatandaşları arasına fitnenin sokulduğu, karmaşanın, huzursuzluğun ve yoksulluğun arttığı bir dönem olmuştu.

Yukarıda zikredilen olayların canlı şahitlerinden birisi olan Hasan Basri Çantay, Osmanlı'nın yenilgisine müteakip, memleketin her tarafında büyük bir karışıklığın ve ümitsizliğin hâkim olduğunu belirtmektedir. $\mathrm{O}$, başta İstanbul olmak üzere, Anadolu'nun birçok ilinin yabancıların egemenliği altına girdiğini; Türklerle yıllarca yan yana yaşayan ve bir kısmı devlet yönetiminde bulunan Rum ve Ermeni asıllı vatandaşların, yenilgiden sonra Türklere hakaret etmeye, iftiralar atmaya başladığını ifade etmektedir. Ayrıca Hasan Basri, o sıralarda Anadolu'da eşkıyalar türediğinden, köy ve kasabaların yağmalandığından ve Müslümanlara işkenceler yapılmaya başlandığından söz etmektedir (Çantay, 1964, s. 5-6). Dolayısıyla onun

anlaşmaları gündemde oldu. Başka bir ifadeyle bu konferansta Yunanlıların Batı Anadolu'yla ilgili isteklerinin yerine getirilmesi başta olmak üzere Osmanlı Devleti'nin topraklarını paylaşma planları yapıldı (İlgürel, 1999, s. 4-5; Belen, 1973, s. 19-23).

17 Sevr Antlaşması; bir tarafta Müttefik Devletler; Britanya İmparatorluğu, Fransa, İtalya, Japonya ile onlara Ortak Devletler; Ermenistan, Belçika, Yunanistan, Hicaz, Polonya, Romanya, Yunanistan, Sırp-Hırvat-Sloven Devleti Çekoslovakya; diğer tarafta Türkiye (Osmanlı Devleti) 10 Ağustos 1920 da Fransa'da Paris'in güneybatı kesimindeki Sevr'de imzalanmıştır. Çok ağır şartlar içeren bu antlaşma ile Osmanlı toprakları neredeyse tamamen yok sayılmış, Türkler için sadece Orta Anadolu'da küçük bir kısım bırakılmıștır. Fakat TBMM'nin 7 Haziran 1920 tarihinde kabul ettiği bir kanunla, İstanbul'un işgal edildiği 16 Mart 1920 'den sonraki İstanbul Hükümetinin yaptığı ve yapacağı bütün antlaşmalar ve icraatlar geçersiz kılındığı için, Sevr Antlaşması Yeni Türkiye Hükümeti tarafından başından beri geçersiz kabul edilmiştir (Demirel, 2010, s. 113-114); Sevr Antlaşmasının maddeleri ve antlaşmanın yorumları hakkında geniş bilgi için bk. (Öztürk, 2007).

1825 Maddelik Mondros Mütarekesi; Birinci Dünya Savaşı'nı bitirmekle birlikte çok ağır şartlar taşımakta, Osmanlı Devleti'nin bağımsızlığını yok etmekte, ordusunun terhisini ve silahlarının teslimini öngörmekteydi. Bununla Çanakkale ve İstanbul boğazlarının kontrolü İtilaf Devletlerinin eline geçmekteydi. Mütareke, söz konusu devletlere, güvenliklerini tehdit ettiği gerekçesi ile Osmanlı topraklarının herhangi bir kısmını işgal etme hakkını tanımaktaydı. Bu çerçevede özellikle Mütarekenin iki maddesi çok önem arz etmekteydi. Örneğin 7. maddesine göre, Müttefikler güvenliklerini tehdit eden bir durum olduğunda Osmanlı Devleti'nin stratejik bütün noktalarını işgal edebileceklerdi. Buna ilaveten 24. Maddeye göre ise "Ermenistan vilayetlerinin birinde" karışıklık çıkarsa, Müttefikler o vilayetlerin bir kısmını işgal etme yetkisine sahip olacaklardı. Büyük devletler Mütareke'nin bütün bu hükümlerini yavaş yavaş uygulamaya koymaya başlamışlardı (Demirel, s. 11; Akyüz, s. 41- 42).

${ }^{19}$ Wilson İlkeleri'nin 12. maddesi şöyleydi: "Halihazırdaki Osmanlı İmparatorluğu'nun çoğunluğu Türk olan kısımlarına, itirazsız egemenlik verilmesi, Türk boyunduruğuna tâbi diğer milliyetlere emniyeti mutlaka içinde, varlıklarını baskı altına almaksızın gelişmelerinin garanti altına alınması. Çanakkale Boğazı'nın uluslararası teminat altında, bütün milletlerin ticaret gemilerinin serbestçe geçebilmesi için açık kalması." (Albayrak, 1998, s. 2).

${ }^{20}$ Hasan Basri, Batı Anadolu'da bulunan Yunan nüfusuyla ilgili şunları anlatmaktadır: "...Venizelos, bu meşru' olmayan talebini tervîc ettirmek için hayâl kuvvetiyle memleketlerimizde Rum nüfusunun İslam nüfusundan fazla olduğunu Paris'teki sulh konferansında resmen söylemekten sıkılmıyor, 'maksada vusul için her şey...' nazariyesini fi'len tatbik etmiş oluyor..." (Çantay, 1964, s. 70); Venizelos'un Anadolu planlarıyla ilgili geniş bilgi için bk. (Pallis, 1997, s. 23-56). 
sözünü ettiği bütün bu olaylar ve onun din, vatan ve millet sevgisi, Hasan Basri'yi Millî Mücadele çalışmalarına katılmaya mecbur etmiştir. Bu çerçevede o, bu mücadeleye bir gazeteci olması hasebiyle başta basın olmak üzere, bölgesel ve yöresel kongrelere katılmaya çalışarak, Balıkesir'deki Millî Müdâfaa Heyeti'nin oluşmasında organizatör rolü üstlenerek ve Balıkesir milletvekili olarak Millî Mücadele'ye katkı yapmaya çalışmıştır.

\subsection{Basın Yoluyla Katkıları}

Bir gazeteci olarak Hasan Basri, II. Meşrutiyet'in ilanından sonra Balıkesir'de yayın faaliyetini sürdüren Nasihat ve Balıkesir gazetelerinde yazılar yazdı. Ayrıca o, Samih Rifat Bey'in mutasarrıflığı zamanında Ylldırım isminde bir gazete çıkardı ve daha sonra mutasarrıf Reşid Bey'in emriyle Karesi adlı bir gazete yayımladı (Işık, 1993, s. 218). Bu çerçevede Hasan Basri, memlekette ve Balıkesir'de meydana gelen olumsuz durumdan rahatsızd ve buna bir dur demek gerektiğine inanıyordu. Bu amaçla bir gazeteci olarak o, "Ses" adında bir gazete çıarmak ve bunu milletin yükselen sesi yapmak istiyordu. Hasan Basri, çevresindeki insanların bu işe çok olumlu bakmamasına, hatta ümitsiz bakmasına rağmen, 17 Ekim 1918'de gazetenin ilk sayısını çıkartarak memleketin her tarafına gönderdi (Yazıcı, 1993, s. 431). Bu gazetenin baş kısmına, çok değer verdiği dostu Mehmet Âkif'in özellikle bu gazete için yazıp gönderdiği, Millî Mücadele'yi tetikleyici çok manidar şu dörtlüğü koydu:

"Düşman sesi duymak istemezsen,

Kardeş sesidir uyan bu sesten!

Kalkınca görür ki akşam olmuş

Vaktiyle uyanmayan bu sesten. ${ }^{21}$

Nitekim Hasan Basri'nin Millî Mücadele'ye en önemli desteği kalemiyle olmuştur. Özellikle onun çıkardığı bu Ses Gazetesi, Mütareke yıllarının en hür ve en yürekli yazılarının yayınlandığı ve zaman zaman İngilizlere, Yunanlılara bile çatabilen cesur gazete olmuştu. ${ }^{22}$ Gazetenin Anadolu'nun çeşitli yerlerinde bulunan fahrî muhabirleri; işgal kuvvetlerinin zorbalıklarını, baskılarını ve terör olaylarını ilk kez bu gazete vasıtasıyla kamuoyuna duyurmuşlardı. Aynı şekilde Ses'te iç ve dış düşmanların gizli planlarıyla ilgili haberler de çıkmıştı. Örneğin, muhtelif yerlerdeki Ermenilerin Adana ve civarında toplanarak bir Ermenistan kurmak üzere, cebren tehcir vazifesiyle mükellef bir komitenin varlığı, ilk defa bu gazetede haber olmuştu. Böylece millet, memleketi kurtarmak için silahlı mücadeleden başka çare olmadığını anlamış ve Millî Mücadele adına yapılan çalışmalara destek vermişti (Vakkasoğlu, 1987, s. 35).

Hasan Basri Çantay, gazetedeki yazılarıyla memleketin içine düştüğü zor günlerde millete ümit ve heyecan verirken, iç ve diş düşmanlara ve bozgunculara korku ve ümitsizlik vermiştir. O, Yunanlılarla ilgili bir yazısında şunları yazmıştır: "... Fakat merak etmeyiniz okuyucularım! Umumî vicdan ve bilhassa Müslümanlık ölmeyecek, bu kara günlerin acısını unutmayacaktır. Asabî kalem, bir türlü hak isbatına tenezzül etmek istemiyor, Türk kanım nimet kâfirlerine karşı, "evet haklıyım" demeyi bile kendisine bir zül addediyor. Çünkü, hak, hakdır; güneş güneştir. Acaba Yunanlılar, memleketimizin her tarafinda kaynaşan, memleketimizin zirâatine, ticâretine, irfan ve medeniyetine hâkim olan yüz binlerce Türk'ü göremiyorlar mı? Memleketimin, bütün livâmızın kucakladığ türbeler, camiler, mescidler, tekkeler, medreseler, mektepler, imaretler, hanlar, hamamlar, kervansaraylar, dükkanlar, mağazalar, köprüler, yollar...Kimindir? Türk'ün mü yoksa Yunan'ın mı? Hatta merkezine nispetle çokluğu teşkil eden

\footnotetext{
${ }^{21}$ Hasan Basri, Ses'in başında sürekli yer alan Mehmet Âkif'in bu dörtlüğünden "...gazetemin başında bir tâcl san'at ve hamiyyet gibi parladı, durdu." diyerek, övgüyle bahsetmektedir (Çantay, 1966, s. 24).

${ }^{2}$ Hasan Basri'nin Yunanlılara karşı çıtığını gösteren, 14 Kasım 1918'de Ses'te yayınlanan "Rumlar Mi Mazlum? (Amanoloidi Efendiye)" başlıkla yazısı ilginçtir. O, bu yazısında Amanoloidi'nin; Karadeniz, Çanakkale, Marmara ve Adalar sahillerinde 550.000 Rum'un Türkler tarafından katledildiği ile ilgili Meclis-i Mebusan'a sunduğu bir rapora cevap vermektedir. Onun verdiği bu cevaba Amanoloidi'nin yalanlamadığı da ifade edilmektedir (Çantay, 1964, s. 48-50).
} 
Ayvalık misafirlerinin nesi, ne eseri, ne marifeti vardır? Evlerini tünettikleri arazi bile Medine-i Münevvere vakfıdır!" (Çantay, 1964, s. 72; Vakkasoğlu,1987, s. 37-38).

Hasan Basri, Mütareke devrinde yer yer tutuklamaların başladığını, Gayri Müslim vatandaşların gittikçe şımardığını ve Türkler aleyhine sürekli yazılar yazdıklarını belirtmiştir. Kendisinin onlara Ses yoluyla cevap verdiğini ve ümidini yitirmiş halka ümit vermeye çalıştığını ifade etmiştir (Çantay, 1964, 60-62). Hatta o, zaman zaman Ermeni ve Rumlarla kavgalar yapmış, bunlara karşı herkesi "Milli Hareket"e katılmaya çağırmıştır (Çantay, 1964, 67; s. 66-70). Bu gazetenin yukarıda zikredildiği gibi Türk halkında millî heyecanlar uyandıracak şekilde yayınlar yapması İngilizleri rahatsız etmiş ve gazete takibe alınmıştır. İngilizler bir süredir takip ettikleri gazeteyi kapattırmak için İstanbul Hükümeti'ne bask1 yapmaya başlamıştır. Hatta gazetenin Bolşevik yanlısı olduğu iftirası bile atılmıştır. Dahası Ses'in bir başka adla tekrar yayınlanmaması ve sahibinin de Dîvân-1 Harb'e sevkiyle ilgili bir sürü girişimde bulunulmuştur. Bütün bu girişimlerin sonucu gazetenin kapatılması ve müdürü Hasan Basri Çantay'ın Dîvân-1 Harb'e tevdii yönünde Meclis-i Vükelâ'dan (Osmanlı Devleti'nde Sadrazamın başkanlığındaki Şeyhülislamla diğer nâzırlardan meydana gelen meclisin adı; vekiller meclisi) karar çıkartılmıştır. Sonunda Ses Gazetesi başlangıçtan itibaren 22 sayı yayınladıktan sonra 13 Mart 1919'da kapatılmıştır (İlgürel, 1999, s. 8-12). Hasan Basri, gazetenin kapatılmasını bir taraftan Ermeni ve Rumların, diğer taraftan haklarında sert yazılar yazdığı ihtikar ve eşkıyaların takipleri yüzünden olduğunu belirtmiştir (Çantay, 1964, s. 6-7; Çantay, 1966, s. 24). Ses'in kapatılması ve Hasan Basri hakkında verilen tutuklama kararı, onun için dokuz aydan fazla sürecek olan zor ve sıkıntılı kaçış sürecinin başlaması demektir (Akarslan, 1998, s. 97). Hatta o, bu kaçış sürecini ve gazetenin kapatılışını kendi Millî Mücadelesinin susturulması olarak nitelendirmiştir (Çantay, 1964, s. 66).

\section{3. İzmir Müdâfaa-i Hukuk Cemiyeti Kongresine Katılması}

Hasan Basri'ye göre, Mondros Mütarekesi'nin akabinde, işgal olaylarının başlaması üzerine, memleketini ve milletini seven insanlarda, Müdafaa-i Hukuk düşüncesi gelişti. Çünkü memleketi kurtarmak için Osmanlı Devleti'nin ne hükümeti ne de ordusu yeterliydi. Özellikle Damat Ferit Paşa hükümetinin Batı Anadolu'da meydana gelen olaylara seyirci kalması, dahası halka sükûnet ve itidâl tavsiye etmesi, bizzat halkın kendi kendini savunma zorunluluğunu ortaya koydu (Selek, 1966, s. 113-114).

Halkın kendini ve vatanının savunma düşüncesiyle ortaya çıkan Müdâfaa-i Hukûk'un amacı Türk Milletinin ve yurdunun geleceğini, her türlü yöntemi kullanarak kurtarmaktı. Bu amaçla 1 Aralık 1918'de kurulan cemiyetlerden ilki İzmir Müdâfaa-i Hukûk-i Osmâniye Cemiyeti (Osmanlı Haklarını Savunma Cemiyeti)'dir. ${ }^{23} \mathrm{Bu}$ cemiyetin en önemli faaliyetlerden birisi, 17-19 Mart 1919 tarihleri arasında gerçekleștirdiği Müdâfaa-i Hukûk Cemiyeti Büyük Kongresi'dir (Albayrak, 1998, s. 41-45). Bu kongre, İzmir Valisi ve bölge kumandanı Nureddin Paşa'nın, vatanın savunmasıyla ilgili dağınık çalışmaları bir noktada toplamak, halkın maneviyatını yükseltmek ve Ege'nin Türk olduğunu dünyaya duyurmak için yapmayı amaçladığı bir kongredir. Kongre; İzmir, Manisa, Aydın, Denizli ve Balıkesir'den gelecek delegelerin katılımıyla oluşacaktır (Bayar, 1967, s. 1630-1634). Bu kongre, sonradan yapılacak olan faaliyetlere örnek teşkil etmesi bakımından Illk Redd-i İlhak (vatan topraklarının işgal edilmesini önlemek) mahiyetinde olduğu için önemli bir girişim olmuştur (Kutay,1972, s. 4344). Kongre haberi Batı Anadolu'nun diğer şehirlerinde olduğu gibi Balıkesir'de de büyük ilgili uyandırmıştır. Bunun üzerine Balıkesirli aydınlar ve halkın ileri gelenleri toplanarak, Balıkesir'den katılacak olanları seçmişlerdir. Kongrede Balıkesir merkezini temsil edecekler

\footnotetext{
23 Mondros Mütarekesi'nden sonra memleketin üzerine çöken ümitsizliği ve kötümserliği yok etmek için yurdun farklı bölgelerindeki bazı vatanperverler bir araya gelerek cemiyetler oluşturmuştur. Bu cemiyetlerden ilki, 1 Aralık 1918'de kurulan İzmir'de kurulan İzmir Müdâfaa-i Hukûk-i Osmâniye Cemiyeti'dir. Cemiyetin kuruculariyla ilgili olarak bk. (Bayar, 1967, s. 16191620); ikincisi, 2 Aralık 1918'de Edirne'de kurulmuş olan Trakya-Paşaeli Müdâfaa-i Hukûk Heyet-i Osmâniye'dir. Üçüncüsü ise 4 Aralık 1918'de İstanbul'da kurulan fakat daha sonra Erzurum'da teşkilatlanan Vilâyât-1 Şarkiye Müdâfaa-i Hukûk-i Milliye Cemiyeti'dir (İlgürel, 1999, s. 5-6).
} 
arasında Hasan Basri Çantay da vardır (Akarslan, 1998, s. 55-57; Uğur, 1994, s. 47; Çantay, 1964, s. 7).

Hasan Basri, söz konusu kongreye Balıkesir Murahhası (Delegesi) olarak katılmak için 15 Mart 1919 yola çıkacaktı. Onun beraberinde de Balıkesir vilayeti ile ilgili genel durumu gösteren evraklar vardı. O, bu evraklara istinaden bir raporu da kongreye sunacaktı. Kongreye sunacağ bu raporla Balıkesir ve havalisinin Türk olduğunu ispatlamaya çalışacaktı. ${ }^{24}$ Hasan Basri, İzmir'deki söz konusu kongreye katılmak için trenle yola çıktığında, kendisinin takip edildiğini anlamış, bunun üzerine bir arkadaşıyla birlikte Manisa'da trenden inmiştir. $\mathrm{O}$, bir sonraki trenle İzmir'e gitmiş ve arkadaşlarının kaldığ kadar uyumamış ve Kongre'ye sunması gereken raporu hazırlamıştır (Yazıcı, 1993, s. 434). O, 16 Mart 1919 sabahında arkadaşlarıyla beraber buluşmuş ve Nureddin Paşa'yı ziyaret etmiş̧lerdir. Nureddin Paşa, muhtemel tehlikeye karşı gizlice hazırlanmaları konusunda onlara tavsiye ve talimatlarda bulunmuştur. Hasan Basri, Kongre'nin bașlayacağı 17 Mart 1919 sabahı, kendisinin tutuklanacağı haberi üzerine, sadece Hocası Müftü Efendi'ye ve Balıkesir Maarif Müdürü Sabri Sözen'e durumu bildirmiş, hazırlamış olduğu raporu ve diğer evrakları Sabri Bey'e teslim ederek otelden ayrılmıştır (Çantay, 1964, s. 8-9).

Hasan Basri, otelden ayrılmadan arkadaşı Mehmet Câvid Bey'le önce Karşıyaka'ya sonra da Bergama'ya, oradan da Burhaniye'nin Pelit köyüne gitmek konusunda anlaştı. O, uzun ve meşakkatli geçen bir yolculuktan sonra Bergama'ya ulaşt1. ${ }^{25}$ Hasan Basri, Bergama'ya ulaşınca kasaba civarında bir çiftliğe gitti. Kendi ifadesiyle o sırada Bergamalılar arasında İttihat-İtilaf tartışmaları yapılmaktaydı. O, çiftlikte kaldığı sırada, bazı ileri gelenlere yaptığı sohbetlerde; Venezilos başta olmak üzere diğer İtilaf Devletlerinin ileri gelenlerinin memleketi paylaşma planlarından, vatanın ve milletin bütünlügünden, millî birlik ve beraberliğin öneminden söz etti (Çantay, 1964, s. 16-17).

Hasan Basri'nin çiftlikte saklandığ 1 siralarda, daha önce 17-19 Mart 1919 tarihleri arasında yapılması planlanan Müdâfaa-i Hukûk Cemiyeti Büyük Kongresi de yapılmıştır. Bu Kongre'ye büyük çoğunluğu İzmir, Manisa, Balıkesir, Aydın, Muğla ve Denizli gibi illerden belediye başkanları, müftüler ${ }^{26}$, belediye meclis üyeleri ve sivil toplum kuruluşlarından oluşan 165 kişi katılmıştır. Ayrıca Kongre'yi çok sayıda basın mensubu izlemiştir. Bu açıdan Kongre Millî Mücadele öncesinde Anadolu'da toplanan en fazla katılımlı kongre olmuştur. Kongre'de hararetli konuşmalar yapılmış ve sonunda İzmir'in işgaline karşı "silahlı direnişe geçilmesi" yönündeki en önemli karar alınmıştır. Ayrıca kongrenin bitiminde dört maddeden oluşan bir

\footnotetext{
24 (Çantay, 1964, s. 7-8); Hasan Basri söz konusu kongrede Balıkesir ve havalisinin Türk olduğunu ispatlamaya çalışacaktı. Çünkü, Yunan Başbakanı Eleftherios Venizelos (1864-1936), Büyük Yunanistan idealini gerçekleştirmek istiyordu. Bu yüzden o, sahte istatistiklere, uydurma haritalara istinaden Batı Anadolu'daki nüfusun büyük çoğunluğunun Rumlardan oluştuğunu iddia ediyordu. Böylece o, Batı Anadolu'yu Yunanistan'a katmak için elinden geleni yapıyor ve bu konuda İtilaf Devletlerini ikna etmeye çalışıyordu. Ayrıca Venizelos ve Yunanistan yönetimi; Batı Anadolu'yu elde edebilmek için bölgeye silah ve malzeme taşımanın yanında, başta Ege adalarından olmak üzere Yunanistan'ın diğer bölgelerinden Rumları bölgeye yerleştirmeye başlıyordu. (Albayrak, 1998, s. 15-30; Akyüz, 1975, s. 68-83); Ayrıca Venizelos ile ilgili değerlendirmeler için bk. (Gülmez, 1999, s. 199-202). 25 Hasan Basri Çantay, İzmir'den Bergama'ya gidişi sürecinde oldukça zor günler yaşadı. O, İzmir'de önce, kılık ve kıyafetini değiştirdi, gözlüklerini çıkardı ve Salim adında bir öğretmen kimliğine büründü. Hasan Basri, bütün eşyaları ve parası otelde kaldığı için, Câvid Bey'den bir miktar para aldı ve bir araba kiralayarak yola çıktı. Kış mevsimi ve yolların çok kötü olması sebebiyle o, çok zorlu bir yolculuktan sonra Ali Ağa Çiftliği adında bir nahiyeye (kasabaya) geldi. O, orada sahil güvenlikten sorumlu bir asker tarafından nahiye müdürüne (Râtib Bey) götürüldü ve sorgulandı. Hasan Basri yakalandığını zannederek kendisiyle ilgili hiçbir şeyi gizlemeden olduğu gibi Râtib Bey'e anlattı. Aralarında geçen uzun bir konuşmadan sonra, nahiye müdürü onu serbest bıraktı. Serbest kalınca Hasan Basri arabacı Ali'yi bulup kendisiyle ilgili gerçekleri anlattıktan sonra 18 Mart 1919'da Menemen'e gitti. O, Menemen'de bir hana yerlești, han sahibi Mustafa Efendi'ye kendisini tanıttı, o da onu gıyaben tanıdığını ve sevdiğini, kendisini yakalatmamak için elinden geleni yapacağı teminatını verdi. Hasan Basri, ona Bergama'ya, oradan da Balıkesir tarafına gitmek istediğini belirtti. Bu konuda han sahibi kendisine yardım edeceğini ifade etti; Hasan Basri'yi Menemen'li bir fistık tâciri sıfatı ve kıyafeti uydurdu. Ayrıca o, handa bulunan Arnavud Şaban adında birisinin hayvanıyla onun Reşadiye'ye kadar gitmesine yardımcı oldu. Hasan Basri, sıkıntılı bir yolculuktan sonra Reşadiye nahiyesine vardı. Reşadiye'nin müdürü onun dostu ve gazetesinin muhabirlerindi. Nahiye müdürü kendisini çok iyi karşıladı ve güzel bir şekilde ağırladı. Fakat tutuklanma emri buraya da geldiği için, dostu onun Bergama'ya gitmesine yardım etti (Çantay, 1964, s. 9-16).

${ }^{26}$ Millî Mücadele Döneminde din adamalarının faaliyetleriyle ilgili geniş bilgi için bk. (Sarıkoyuncu, 2002).
} 
telgraf metnin ${ }^{27}$ Paris'teki Barış Konferansı'na gönderilmesi kararlaştırılmıştır. Aslında bu telgraf, hem Batı Anadolu'da meydana gelen olaylara Türk aydınlarının seyirci kalmadıklarının hem de gelecekte meydana gelecek olaylara uygar yöntemlerle çözme isteğinin bir göstergesiydi. Dolayısıyla İzmir Müdâfaa-i Hukûk-i Osmâniye Cemiyeti ve onun düzenlediği Büyük Kongre, Batı Anadolu'da bağımsızlık ateşinin yakılmasına öncülük etmiştir (Albayrak, 1998, s. 46-51; Moral1, 1973, s. 6-7).

Büyük Kongre'nin bitimine müteakip, Hasan Basri'nin arkadaşı Mehmet Câvid Bey, İzmir'de sözleştikleri gibi 26 Mart 1919'da çiftliğe geldi. Onun gelmesinden önce Hasan Basri çiftlikte yakalanma tehlikesi geçirdi. Sonuçta Hasan Basri beş gün kaldığ birlikte ayrılmak zorunda kaldı. Onlar, Kozak Nahiyesi'den geçerek Bağyüzü'ne vardılar (Çantay, 1964, s. 17-18). Hasan Basri Bağyüzü'nde iken, kendisini öldürmek isteyen Rumlardan kaçan Ses Gazetesi'nin Ayvalık muhabiri Sansör Ali Bey'le karşılaştı. Sansör Ali Bey, 24 Şubat 1919 'da Yunan Kızılhaç Heyeti'nin Ayvalık'a gelişiyle ilgili ${ }^{28}$ Ses'e bir mektup göndermiş̧i. Hasan Basri de bu mektupla ilgili gazetede yazılar yazdığından dolayı kendisinin çok sıkıntı çektiğinden, hata bu kaçış olaylarının bununla ilgisi olduğundan söz etmektedir. ${ }^{29}$

Hasan Basri ve arkadaşı Mehmet Câvit Bey, Bağyüzü'nden ayrılarak Armutova üzerinden Pelit Köyü'ne gitti. O, burada Mehmet Câvit Bey'in evinde dokuz gün kaldı. Arkadaşının akrabalarıyla görüştü, orada görüştüğü insanların, memlekette olup bitenden çok haberi yok gibiydi. Hasan Basri yine arkadaşının yardımıyla Burhaniye'ye geçti ve orada Hacı Tâli Bey adında birinin çarşıdaki mağazasının üstündeki bir odada misafir oldu. Fakat o, kendisini misafir eden, yardım eden kişilere sıkıntı verdiği ve yük olduğu için üzülüyordu. Bunun yanında o, kaçışıyla mağdur ettiği ailesi için de ayrıca üzülüyordu. Hasan Basri zaman zaman bu kaçışın sebebini sorguluyordu. "Kendi vatanımda sırf Türk olduğumdan dolayı, ma'ruz kaldığım bu felaket ve esaret gücüme gidiyor..." (Çantay, 1964, s. 23), diyerek sitem ediyordu. Hatta o, kaçış yerine hapiste olmanın bile daha iyi olacağını düşünüyordu. Dahası o, bazen intihar etmeyi bile düşündügünü ve dindarlığının buna engel olduğunu ifade ediyordu (Çantay, 1964, s. 21-24).

Hasan Basri, Burhaniye'de iken bir şekilde kaymakam Salim Özdemir'le görüşmüştür. O, kaymakamla muhtemel Yunan tehlikesine karşı neler yapılabileceğiyle ilgili istişare yapmıştır. Fakat Hasan Basri burada da uzun kalamamış, onun Balıkesir'e gitmesi uygun görülmüştür. $\mathrm{O}$, Balıkesir'de kendisi için hazırlanan, dört odada üç ailenin barındığı bir evin yukarı katında karanlık bir odada saklanmıştır (Çantay, 1964, s. 24-26). Hasan Basri Çantay, o evde saklandığg süre içinde, kimse varlığından haberdar olmasın diye çok sıkı şartlara uymak zorunda kalmıştır. Fakat o, samimi dostları ve kayın pederi vasıtasıyla Balıkesir'de ve memlekette olup bitenlerden haberdar olmuştur. Bu sırada Balıkesir mutasarrıfı Hasan Vassaf görevinden alınmış yerine Ahmed Hilmi Bey getirilmiştir. Hasan Basri, onun hakkında bir araştırma yaptırmış, onun iyi olduğuna kanaat getirince kendisinin Balıkesir'de olduğunu ona bildirmiștir. ${ }^{30}$

\footnotetext{
${ }^{27}$ Müdafaa-yı Hukuk Cemiyeti'nin Kongresi'nin, Paris Barış Konferansı'na göndermeye karar verdiği telgrafta özetle: İlk olarak, Türk Milletinin, Galip Devletlerden kendinin imha edilmeyeceğine dair teminat istenmesi; ikinci olarak, Doğu'da yaşayan Türk halkının maddî ve moral kalkınmasıyla millî bağımsızlı̆̆ının, XV. yüzyıldan beri Türk Milletinin kültürel merkezi olan Başkenti'nin (İstanbul) korunmasına bağlı olduğu; üçüncü olarak Aydın Vilayeti ile Karesi ve Menteşe Sancaklarında nüfusun yüzde seksen beşinin Türk olduğu, mülk ve servet bakımından da aynı oranda temsil edildikleri; dördüncü olarak ise Türk Milletinin, Büyük Devletlerin adaletine güvendiği, kendisini felakete sürükleyen tehlike karşısında, tabii haklarını korumak için yalnız bırakılmaması gerektiği vurgulanmaktadır (Albayrak, 1998, s. 48-49).

${ }^{28}$ İzmir'in işgali öncesinde bölge halkına ilaç ve tıbbî araç getirdiğini iddia eden, fakat aynı zamanda Yunan subaylarını da taşıyan Yunan gemileri Batı Anadolu kıyılarına sık sık gelmekteydi (Albayrak, 1998, s. 121).

${ }^{29}$ Sansör Ali'nin söz konusu mektubu, Birinci Dünya Savaşı sonrası Ayvalık ve civarında yaşanılanları anlatması bakımından önemlidir. Söz konusu mektup metni için bk. (Çantay, 1964, s. 19-21).

30 (Çantay, 1964, s. 27-29); Hasan Basri'nin Balıkesir'de saklandığı sıralarda kendisine çok yardımcı olan dostları olduğu gibi, kendisini üzen arkadaşları da olmuştur. O, samimi olarak bildiği bir iki arkadaşına Balıkesir'e geldiğini bildirmişti. Fakat bu arkadaşları onun geldiğini başkalarına söyleyince, hakkında takibatlar artmıştır. Kendisini takip edenler arasında; gayrı Müslim vatandaşlar, kozmopolitler, aleyhinde yazı yazdığı şakiler, İngiliz Muhipler Cemiyeti erkanı, takip memurları ve İngiliz mümessili gibi kimseler vardır. Hatta o, kendisini takip eden 22 memurdan ve başına konulan 600 liralık ödülden söz etmiştir. Bundan dolayı
} 
Hasan Basri, "Kara Günler" olarak nitelendirdiği o günlerde; bir taraftan çalışmalarını gizli yürüttü, diğer taraftan Balıkesir'de çıkan Doğru Söz Gazetesi'nde "Hüzn̂̂" mahlasıyla ihtilâl şiirleri yazdı. O, kara günler dediği zamanda kendisini üzen; küçük ruhlu, dar kafalı ve beyinsiz olarak nitelendirdiği kimseler vard1. Bu kimseler Kuvay-1 Milliye ${ }^{31}$ kurulurken ve Millî Mücadele döneminde olumsuz tutum ve davranış içinde olmuşlardı. Fakat aynı kimseler savaş bitip de zafer elde edilince, kendilerini hamiyetperver ve vatanperver ilan etmişlerdi. Hasan Basri'ye göre, Balıkesir'de İlk Millî Müdafaa'nın tesis edilmesi bu türden kimselerle değil; gerçek fazilet ve namus sahibi, genel güvenliği dikkate alarak korkusuzca hareket eden Yusuf İzzet Paşa, Mutasarrıf Hilmi Bey ve Miralay Hurşid Bey gibi kimseler sayesinde olmuştu (Çantay, 1964, s. 31).

Hasan Basri, zikredilen şekilde sıkıntılı günleri yaşarken, 15 Mayıs 1919'da Yunanlılar İzmir'i işgal etti. ${ }^{32}$ İzmir'in işgalinden bir gün sonra İzmir Redd-i İlhak Heyeti yurdun dört bir tarafına olduğu gibi Balıkesir'e de bir telgraf gönderdi. ${ }^{33} \mathrm{Bu}$ telgraf Balıkesir'in ileri gelenleri arasında ilk anda şok etkisi yaptı. Fakat Mutasarrıf Hilmi Bey ve Belediye Reisi Keçecizâde Mehmet Efendi hemen Belediye Meclisini toplantıya çağırdı. Bu toplantıya halktan ve şehirde yaşayan gayrı Müslimlerin ileri gelenleri de katıldı. Toplantıda çözüm için neler yapılabileceği konuşuldu. Sonunda Sadrazam'a ve İtilâf Devletlerinin (İngiliz, Amerikan, Fransız ve İtalyan) siyasî temsilcilerine işgali reddeden bir telgraf gönderildi (Akarslan, 1998, s. 62-66).

\subsection{Balıkesir Millî Müdâfaa Heyeti’nin Oluşmasındaki Katkıları}

Hasan Basri ve arkadaşları İzmir'in işgaline çok üzüldü ve bunun üzerine bazı samimi dostlarıyla bir araya gelerek, Millî Müdâfaa Heyeti oluşturmakla ilgili uzun uzadıya konuştular. Ona göre, bu konuda daha önce fikirleri vardı, fakat bunu bir plan ve program dahilinde uygulamaya koymak gerekiyordu. Böylece onlar, sahip oldukları fikirleri esas alan gizli bir program yaptılar. Bu programa göre Hasan Basri de saklandığı yerden çıkacak, Kepsut ve Dursunbey taraflarına gidecek ve oralarda dikkatleri üzerine çekmeden Millî Mücadele çalışmaları yapacaktı (Çantay, 1964, s. 30-31).

Hasan Basri, planlanan şekilde 20 Mayıs 1919 gecesinde halasının oğlu ve kayın biraderi ile birlikte çete kıyafetleri giyerek ve silahlanarak, Balıkesir'den Kepsut'a gitti. O, Kepsut'da nahiyenin ileri gelenleriyle birlikte bir toplantı yaptı. Sonra o, nahiye müdürü Emin Bey'le birlikte, Kepsut havalisindeki köylerde ve kasabalarda dolaşarak, halkta millî birlik ve beraberlik şuurunu uyandırıcı konuşmalar yapmaya başladı. Bununla birlikte Hasan Basri, memleketi içine düştüğü bu felaketten kurtarmanın ancak birlik ve beraberlikle mümkün olacağına inandığı için, başıboş dolaşan İzzet çetesi mensuplarını da kendi grubuna dahil etti. O, bütün bunları yaparken Balıkesir'le irtibatını da kesmedi, mektuplarla ve kuryelerle olup bitenden haberdar oldu (Çantay, 1964, s. 32-33; Uğur, 1994, s. 17-18).

hem kendisi hem de ailesi sıkıntılı günler yaşamıştır. Saklandığı yerin keşfedilmesi üzerine Çantay, yerini değiştirmek zorunda kalmıș, fakat yeni yeri onun için nispeten daha rahat olmuştur (Çantay, 1964, s. 29-30).

31 Kuvayı Milliye deyimi, Millî Mücadele'de iki anlamda kullanılmıştır. Birincisi "Millî Kuvvetler" yani "Milis" anlamında diğeri Millî Mücadele'yi bütün olarak ifade etmek için. Bu bağlamda Kuvayı Milliye; silahlı halk kuvvetleri, Müdâfaa-i Hukûk ve Reddi İlhak teşekkülleri, Hey'et-i Milliyeler, Kongreler, Ankara'da toplanan Meclis ve bütün bunlara yardımcı olan organlar, Millî Ordu hepsi buna dahildir (Selek, 1966, s. 113). Kuvay-1 Milliye fikrini ilk ortaya koyanlardan birisinin de 57. Tümen Komutanı Albay Şefik (Aker) olduğu ifade edilmektedir. Albay Şefik, 23 Mayıs 1919 tarihinde Harbiye Nezaretine gönderdiği bir raporda "Durumu ıslah için Kuvayı Milliye Teşkilâtı vücuda getirmek en iyi tedbir olacaktır." diyerek bildirdiği belirtilmektedir (Esengin, 1975, s. 2021).

32 İzmir'in Yunanlılar tarafından işgali öncesinde, işgal sırasında ve işgal sonrasında İzmir ve havalisinde yaşananlar ile ilgili geniş bilgi için (Parlak, 1982, s. 311-370); Tasvir-i Efkâr Gazetesinin, 2909, 22 Teşrin-i Sâni 1919, sayı ve tarihli bir yazısına istinaden: İzmir'in Yunanlılar tarafından işgalinden sonra İzmir ve Aydın civarından 140.000 Müslümanın varını yoğunu memleketinde bırakarak, canını kurtarmak için Nazilli ve Balıkesir bölgelerine hicret ettiklerinden bahsedilmektedir. Hatta onlara yardım konusunda Müslüman zenginler göreve davet edilmektedir (Kaplan vd., 1981, s. 133-136).

33 İzmir Redd-i İlhak İlhak Heyeti tarafından Balıkesir'e gönderilen telgraf metni şöyledir: "Belediye Riyâsetine, Türk İzmir 15 Mayıs sabahından itibaren Düvel-i İtilâfiye müsaadesiyle Yunanlılar tarafından işgâl olunacaktır. Bu işgâl ve ilhakı reddediniz. Mitingler tertip ederek keyfiyeti düvel-i muazzama nezdinde protesto ediniz. Silâhla müdafaanın esaslarını hazırlayarak vatan ordusuna iltihak ediniz." Reddi İlhak (Akarslan, 1998, s. 61-62). 
Hasan Basri Çantay, Balıkesir'den aldığı bir mektuptan, "Ayvalık tabur kumandanı Ali Bey'in (Ali Çetinkaya) ${ }^{34}$ Yunanlılara ilk millî kurşunu attı̆̆ını ${ }^{35}$ ve Ayalık cephesinde Yunanlıları bozguna uğrattığını" öğrenince çok sevindiklerini ve efelerle bunu kutladıklarını belirtmektedir (Çantay, 1964, s. 33). Ayrıca o, Yunanlılara ilk kurşunun atılmasında Redd-i İlhak Heyet-i Milliyesi başkanı Mehmet Vehbi Bolak ve arkadaşlarının çok büyük rollerinin olduğunu ifade etmektedir (İlgürel, 1999, s. 37). Yine o, Yunanlıların 1919 Haziran-Temmuz ayları içinde farklı tarihlerde Manisa, Akhisar, Menemen, Kırkağaç ve Bergama gibi birçok yere saldırdığını ve imanlı halkın onlara karşı savaştığını ifade etmektedir. Aynı şekilde o, bütün bunların yanında Damat Ferit yönetiminin ve Balıkesir'de bulunan yabancı temsilcilerin de Millî Müdâfaa'yı engellemek için ellerinden geleni yaptıklarını bildirmektedir. Hasan Basri, söz konusu engellemelere rağmen Soma, Salihli, İvrindi ve Balıkesir'de ilk Millî Kuvvetlerin de ortaya çıkmaya başladığını dile getirmektedir. ${ }^{36}$

\subsection{Balıkesir Kongrelerine ve Sivas Kongresi'ne Katılma Çabaları}

Hasan Basri, Kepsut'da bulunduğu sırada, Hacim Muhittin (Çarıklı) Bey'in ${ }^{37}$ Balıkesir'e gelmesiyle 28 Haziran 12 Temmuz 1919 tarihleri arasında Birinci Balıkesir Kongresi düzenlenmiştir. ${ }^{38}$ Hasan Basri, bu kongreye Kepsut'dan belediye başkanı Şakir Bey'in katıldığını ve kongrede konuşulanlar hakkında ondan bilgi almaya çalıştığını bildirmektedir. Yine Balıkesir'den aldığ 1 bir mektuptan Anafartalar Kahramanı Mustafa Kemal Paşa'nın isyan ettiğini ve onun Anadolu'da millî birlik hükümeti kurmaya çalıştığıyla ilgili haberler aldığını ifade etmektedir. Hasan Basri, artık hükümetsiz ve başsız kalmaktan kurtulacakları için bu habere çok sevindiklerini belirtmektedir (Çantay, 1964, s. 35).

İzmir'in işgali sonrasında Anadolu'da Yunan ilerleyişinin hızla devam ettiği sıralarda ${ }^{39}$; Yunan saldırılarına karşı Balıkesir'i savunmak ve birlikte mücadele etmek için çok önemli kararların alındığı Ikkinci Balıkesir Kongresi 26-30(31) Temmuz 1919 tarihleri arasında yapılmıştır. ${ }^{40}$ Hasan Basri, kendisinin bu kongreye katılıp katılmadığ 1 ile ilgili herhangi bir bilgi vermemektedir. Ancak kongreye katılanların listesiyle ilgili kaynaklar incelendiğinde, onun Kepsut'dan delege olarak katıldığı anlaşılmaktadır (Albayrak, 1998, s. 129; Balıkesir ve Alaşehir Kongreleri..., s. 112; Akarslan, 1998, s. 90). Dolayısıyla onun Kepsut civarındaki köylerde bulunduğu sıralarda yapılan bu kongreye katılmış olması muhtemeldir.

Hasan Basri'ye, 10 Ağustos 1919'da Kepsut'un ileri gelenleri tarafindan gizli bir toplantıya katılmak üzere Balıkesir'e gitmesi gerektiği bildirilir. $\mathrm{O}$, bu haber üzerine Kepsut'a

\footnotetext{
34 Ali Çetinkaya'nın Millî Mücâdele öncesi, Millî Mücadele dönemi, Osmanlı Mebusan Meclisi'ndeki ve TBMM'deki faaliyetleri hakkında geniş bilgi için bk. (Kurtuluş Savaşı'na Yön Verenler, Cumhuriyet'in Kuruluşunun 70. Yı1 Armağanı, 1994, s. 139-149); Ayvalık'ın işgali ve Ali Çetinkaya'nın Yunanlılara karşı mücadelesi hakkında ayrıca bk. (Bayar, 1972, s. 2485-2500).

35 Ayvalık Bölge Komutanı Ali Çetinkaya'nın 29 Mayıs 1919'da Ayvalık'ı işgal eden Yunanlılara karşı giriştiği çatışma, Millî Mücâdelenin ilk önemli silahlı direnişi olarak kabul edilmiştir (Albayrak, 1998, s. 122; Akarslan, 1998, s. 75-76).

${ }^{36}$ Çantay, 1964, s. 34; Balıkesir ve civarında oluşturulan millî kuvvetlerle ilgili geniş bilgi için bk. (Apak, 1990, s.49-70).

37 Hacim Muhittin Çarıklı (1881-1965), 1904 yılında Mekteb-i Mülkiye-i Şâhâne'den (Siyasal Bilgiler Fakültesi) mezun olduktan sonra Batı Anadolu'nun birçok ilinde maiyet memurluğu, kaymakamlık, polis memurluğu ve mutasarrıflık gibi birçok görevde bulunmuştur. Ayrıca o, 1917-1918 yıllarında o gün Osmanlı toprakları olan Suriye'deki Havran, Der'a, Haleb gibi yerlerde çeşitli görevlerde bulunmus, bölgenin İngilizlerce işgali üzerine İstanbul'a dönmüștür. O, 26 Ekim 1918'de Karesi Mutasarrıflığına tayin edilmiş, 1 Mart 1919'da yerine Hasan Vassaf Bey'in tayin edilmesiyle açıkta kalmış ve tekrar İstanbul'a dönmüştür. Fakat o, İzmir'in işgali üzerine, millî mücadele çalışmaları için tekrar Batı Anadolu'ya dönmüştür (Balıkesir ve Alaşehir Kongreleri ve Hacim Muhittin Çarıklı'nın Kuvayı Millîye Hatıraları (1919-1920), 1967, s. 9-10).

38 Hacim Bey, daha önce mutasarrıf olarak Balıkesir'de görev yaparken, halkın sevgisini ve güvenini kazanmış birisidir. Onun İzmir'den Balıkesir'e gelir gelmez, kentin ileri gelenlerini toplayarak, ișgal olayı ve genel durum hakkında bilgi edindiği ifade edilmektedir. Yine onun Balıkesir'e gelişinin Batı Anadolu "Millî Hareketi" üzerinde bir katalizör etkisi yaptı̆ğ, İttihat ve Terakki'nin veya tek tek İttihatçıların yerel örgütlerin oluşumunda ve gelișmesinde önemli etkiler yaptığ 1 belirtilmektedir. Hacim Bey'in kente gelişinden sonra, Balıkesir Dar'ül Nafia Medresesi'nde 28 Haziran- 12 Temmuz tarihleri arasında kongre denilebilecek toplantılar yapıldığı ifade edilmektedir. Hacim Bey'in başkan seçildiği bu toplantılarda; Balıkesir'de bir Heyet-i Merkeziye kurulması, kurulan cephelerin ve kazaların ayrı ayrı temsili, cephede yer alan kuvvetlerin hangi kazalar tarafından besleneceği gibi, Redd-i İlhak Heyetlerinin yetki ve görevlerinin belirlenmesi gibi önemli kararların alındığından söz edilmektedir (Albayrak, 1998, s. 124-126; Misıroğlu, 1967, s. 118-122).

${ }^{39}$ Yunan kuvvetlerinin Batı Anadolu'daki ilerleyişle ilgili bk. (Belen, 1973, s. 187-190).

40 İkinci Balıkesir Kongresinde alınan kararlarla ilgili geniş bilgi için bk. (Albayrak, 1998, s. 126-139).
} 
gelişini, nahiyenin ileri gelenlerinin ve halkın kendisini hoş bir şekilde karşılamasını "Adeta alıklaşmışdım. Acaba Balıkesir'den ecnebi mümessil mi gitdi. Bana 'aman gelme, görünme' diye haber gönderen Kuvayi Milliyye Heyeti mi kudret kazandı?" diyerek dile getirir. Kepsut'tan Balıkesir'e giden Hasan Basri'ye, burada yapılan toplantıda kendisinin 4 Eylül 1919'da yapılacak olan Sivas Kongresi'ne delege seçildiği söylenir. Kendisi bunu memnuniyetle kabul ettiğini ve işgal bölgesinden sağ salim gitmesi sağlanırsa hemen yola çıkabileceğini ifade eder. O, birkaç gün Balıkesir'de kalır, fakat yine takip edildiği ve yakalanacağı haberi üzerine tekrar Kepsut'a dönmek zorunda kalır (Çantay, 1964, s. 35-39).

4 Eylül'de başlayacağı kararlaştırılan Sivas Kongresi 4-13 Eylül 1919 tarihleri arasında yapılmış, fakat Hasan Basri bu kongreye katılamamıştır. Kendi ifadesiyle o, 19-29 Kasım 1919 tarihleri arasında yapılan Üçüncü Balıkesir Kongresi'ne ${ }^{41}$ de katılamamıştır. O, bu kongrelere katılamadığı ve geçen süre içinde merkezi heyet tarafından çağrılmadığı için üzüldüğünü dile getirmiştir. Hasan Basri, artık eli kolu bağlı duramayacağına ve vatanın kurtuluşu için kaçma işine son vermesi gerektiğine karar vermiştir. Sonra bütün sorumluluğu üzerine alarak 27 Aralık 1919 Balıkesir'e gelmiş ve özgürce dolaşmaya başlamıştır. Böylece o, 17 Mart 1919'da İzmir'de başlayan ve dokuz ay on gün süren kaçışından sonra, kendisini sanki yeni doğmuş gibi hissetmiş, "Yaşasın hürriyet!" diyerek bu sevincini dile getirmiştir. Hasan Basri, sırf yabancılara esir düşmemek, onların hakaretine maruz kalmamak ve milletine hizmet etmek için kaçtığını ve yakalanmamak için bunca zahmete, meşakkate katlandığını ifade etmiştir (Çantay, 1964, s. 40).

Hasan Basri'nin Balıkesir'de özgür dolaşmaya başladığı sıralarda, İstanbul Meclis-i Mebusan'ı için genel seçimler yapılmıştır. Bu genel seçimlerde Batı Anadolu Millî Heyetleri'nden de adaylar katılmış ve bu adaylar meclisin 28 Ocak 1920 tarihindeki oturumda Misak-ı Millî'nin kabul edilmesinde etkili olmuştur. ${ }^{42}$ Fakat fiilî olarak işgal altında bulunan İstanbul'da Kuvay-ı Milliye yanlısı bir meclisin görev yapması mümkün olmamıştır. Çünkü Yeni Hükümeti kurma görevi verilen ve Meclis'ten güven oyu alan Sadrazam Ali Rıza Paşa Kabinesi, İtilaf Devletlerinin ağır baskısı altında kalmıştır. Bu kabine, bir taraftan Kuvay-ı Milliye'ye yardım etmekle suçlanmış ve diğer taraftan muhalefetin baskısıyla 3 Mart 1920'de istifa etmek zorunda kalmıştır. Bunu firsat bilen Yunan güçleri de Anadolu'nun daha iç kısımlarına kadar ilerlemeye başlamıştır. Ayrıca Anzavur İsyanlarının ${ }^{43}$ yöneticisi Ahmet Anzavur, Biga'yı Kuvay-1 Milliyecilerden kurtaracağını iddia ederek işgal etmiştir. Bütün bunlar Balıkesir'de üzüntüyle karşılanmış ve yeni bir kongrenin toplanmasını zorunlu kılmıştır. Böylece Beşinci Balıkesir Kongresi, hem içteki isyanlara karşı cephelerde hem de cephe gerisinde meydana gelen olayları görüşmek üzere 10-25 Mart 1920 tarihleri arasında toplanmıştır. Kongre toplantılarının devam ettiği sırada 16 Mart 1920 tarihinde İstanbul'un resmen işgal edilmesi ${ }^{44}$ kongrede büyük üzüntü yaratmıştır. Hasan Basri'nin Kepsut'tan delege olarak katıldığı bu kongrede Millî Mücadele'yle ilgili idarî, askerî ve malî olmak üzere çok önemli kararlar alınmıştır. ${ }^{45}$

\subsection{Balıkesir Milletvekili Olarak Millî Mücadele'ye Katkıları}

Hasan Basri, bir taraftan yukarıda zikredilen bölgesel ve yöresel nitelikli kongrelere katılmaya çalışarak Millî Mücadele'ye katkı yapmış, diğer taraftan Birinci Türkiye Büyük Millet Meclisi'nde Balıkesir Milletvekili iken de hizmetlerini sürdürmüştür. ${ }^{46}$ Daha önce söz ettiğimiz

\footnotetext{
${ }^{41}$ Hasan Basri'nin 19-29 Kasım 1919 tarihli olarak belirttiği Üçüncü Balıkesir Kongresi, kaynaklarda Dördüncü Balıkesir Kongresi olarak ifade edilmektedir (Albayrak, 1998, s. 162-163; Arıkan, 1999-2003, s. 469-474).

${ }^{42}$ Hasan Basri Çantay, Misak-1 Millî'nin kabul edilmesinde etkili olmuştur. Ancak onun Misak-1 Milli'nin sınırlarına itiraz ettiği, bu konuda taviz verildiğini düşündüğü ve ayrıca Fransa ile yapılan antlaşmaya da itiraz ettiği ifade edilmektedir. Bununla ilgili geniş bilgi için bk. (Çevik, 2014).

43 Birinci ve İkinci Anzavur (Anzavor) İsyanları ile ilgili geniş bilgi için bk. (Esengin, 1975, s. 65-81; Apak, 1990, s.123-129).

44 16 Mart 1920 tarihinde İstanbul'un işgal edilmesi üzerine, Birinci Türkiye Büyük Millet Meclisi'nde Trabzon Mebusu Nebîzâde Hamdi'nin; İstanbul'un ve memleketin genel durumuyla ilgili hissettikleriyle ilgili Hâkimiyet-i Milliye Gazetesindeki nr.134, 16 Mart 1337/1921 tarihli yazısı için bk. (Kaplan vd., 1981, s. 508-511).

45 Beşinci Balıkesir Kongresi'nin aldığı kararlarla ilgili bk. (Albayrak, 1998, s. 168-180).

${ }^{46}$ Hasan Basri Çantay'ın I. Meclis'teki konuşmaları ve çalışmaları hakkında bk. (Çevik, 2010, s. 115-117; Çevik, 2014; Demirel, 2010, s. 89).
} 
İstiklâl Marşı'nın yazılışı ve kabulü çalışmalarının yanı sıra; onun, TBMM'nde Balıkesir Milletvekili sıfatıyla Millî Mücadelemizin İslâm alemine ve bütün dünyaya duyurulması çalışmalarında da etkin olduğu görülmüştür. Bu çerçevede Yeni Hükümet, 1921 Mart ayında, Millî Mücadelemizin gayesini öncelikle İslâm âlemine ve de bütün dünyaya açıklamak için Ankara'da İlk İslâm Kongresi'nin yapılmasına karar vermiştir. $\mathrm{Bu}$ kongrenin hazırlık çalışmalarını yapmak üzere Burdur Milletvekili ve İstiklâl Şairimiz Mehmet Âkif görevlendirilmiştir. Aynı şekilde Mehmet Âkifin en sadık dostu Hasan Basri'ye de Balıkesir Milletvekili sıfatıyla yapılacak olan kongrenin hazırlama çalışmalarında katiplik görevi verilmiştir. Kongre hazırlıkları büyük bir hızla devam ederken, maalesef Yunan taarruzu başlamış, Mustafa Kemal Paşa cepheye gitmiş ve bütün İslâm dünyasının ileri gelenlerini bir araya getirecek bu kongre yapılamamıştır. ${ }^{47}$

\section{Sonuç}

Balıkesir'in önemli şahsiyetlerden olan Hasan Basri Çantay, çocukluk yıllarından itibaren din, dil, edebiyat, felsefe, hukuk ve iktisat gibi alanlarda, alanında uzman âlimlerden dersler alarak kendini yetiştirmiş ve özellikle de gazetecilik mesleğinde ustalaşmıştır. Yetişmesine vesile olan bu dersler, aynı zamanda onun kalbinde din, millet, vatan ve dostluk gibi değerlere karşı sevginin yerleşmesine ve güçlenmesine sebep olmuştur. Hasan Basri'nin söz konusu değerlere karşı bu sevgisi, kendisiyle aynı değerlere bağlı Mehmet Âkif Ersoy'la dost olmasında veya dostluk kurmasında önemli bir etken olmuştur. Dolayısıyla onların dostluklarının temelini din, vatan ve millet sevgisi oluşturmuştur. Her iki şahsiyetin bu değerler çerçevesindeki dostlukları; Millî Mücadele döneminde Mehmet Âkif'in Balıkesir'e gelerek halkı düşmanla mücadele konusunda teşvik edici konuşma yaptığı sırada, Ankara'da İstiklâl Marşı'nın yazılması, tamamlanması ve kabulü aşamasında ve İlk Meclis'teki millet vekillikleri sırasında güçlü bir şekilde devam etmiştir.

Hasan Basri Çantay'ın, Mehmet Âkif'le din, vatan ve millet sevgisi bağlamında kurduğu dostluk gibi, onun dinine, vatanına ve milletine olan sevgisi, memleketin içinde bulunduğu zor zamanlarda vefa duygusuna dönüşmüştür. $O$, vatanına ve milletine olan vefasını Millî Mücadele döneminde, vatanın düşman istilasından kurtarılması için elinden gelen her türlü fedakârlığı yapmaya çalışarak göstermiştir. Bu çerçevede Hasan Basri, bir gazeteci olarak kendi çıkardığı ve başka gazetelerde Millî Mücadele'ye yönelik yazılarla toplumu uyarma görevini yerine getirmiştir. Bu yazıları sebebiyle o, tutuklanma tehlikesi yaşamış ve yaklaşık on ay gibi bir süre kaçak hayatı yaşamıştır. Ancak bu süreçte o, İzmir'de düzenlenen Müdâfaa-i Hukuk Cemiyeti Kongresi'ne giderek, Balıkesir'deki Millî Müdâfaa Heyeti'nin oluşmasını organize ederek, Balıkesir Kongrelerine ve Sivas Kongresi'ne katılmaya çalışarak Millî Mücadele'ye katkılarını sürdürmüştür. Daha sonra Hasan Basri Çantay, hem İstiklâl Marşı'nın yazılması ve kabul edilmesi aşamasında hem de TBMM tarafindan Millî Mücadelemizin İslâm âlemine duyurulması amacıyla Ankara'da toplanması planlanan İlk İslâm Kongresini düzenleme çalışmaları sırasında dostu Mehmet Âkif Ersoy'la birlikte Millî Mücadeleye katkı yapmıştır. Sonuç olarak her iki büyük şahsiyetin din, vatan ve millet değerleri üzerine kurulmuş olan dostlukları, vatanın ve milletin kurtuluşu sırasında fedakârlık ve vefa olarak kendini göstermiştir.

\section{Kaynakça}

Ağaoğlu, S. (1944). Kuvayı Milliye Ruhu (Birici Türkiye Büyük Millet Meclisi), İstanbul: Nebioğlu Yayınevi.

Akarslan, M. (1998). Türk Millî Mücadelesi'nin Balıkesir Cephesi, Ankara: Kültür Bakanlığı Yayınları.

\footnotetext{
47 (Kutay, 1972, s. 253-263); Hükümetin resmî gazetesi olan Hâkimeyet-i Milliye, nr.130, 11 Mart 1337/1921'de Hüseyin Ragıb'ın "İslam Kongresi" ile ilgili yazısı için bk. (Kaplan vd., 1981, s. 494-496).
} 
Akyüz, Y. (1975). Türk Kurtuluş Savaşı ve Fransız Kamuoyu (1919-1922), Ankara: Türk Tarih Kurumu Basımevi.

Albayrak, M. (1998). Millî Mücadele Dönemi'de Batı Anadolu Kongreleri, Ankara: Atatürk Kültür, Dil ve Tarih Yüksek Kurumu Atatürk Araştırma Merkezi Yayınları.

Alpaslan, T. (2013). Kapitülasyonların Sebep Olduğu Balkan Bozgunu (1912-1913), İstanbul: Kamer Yayınları.

Apak, R. (1990). İstiklâl Savaşında Garp Cephesi Nasıl Kuruldu, Ankara: Türk Tarih Kurumu Basımevi.

Arıkan, Z. (1999-2003). "Millî Mücadele'de Balıkesir", Ankara Üniversitesi Türk Inkılâp Tarihi Enstitüsü Atatürk Yolu Dergisi, 24.

Aydınel, S. (1993). Güneybatı Anadolu'da Kuvâ-yı Milliye Harekâtı, Eskişehir: Kültür Bakanlığı Yayınları.

Balıkesir ve Alaşehir Kongreleri ve Hacim Muhittin Çarıklı'nın Kuvayı Millîye Hatıraları (1919-1920), (1967). Ankara: Türk İnkilâp Tarihi Enstitüsü Yayınları.

Bayar, C. (1966-1972). Ben De Yazdım Millî Mücadele'ye Giriş (1-8), İstanbul: Baha Matbaası.

Belen, F. (1973). Askeri, Siyasal ve Sosyal Yönleriyle Türk Kurtuluş Savaşı, Ankara: Başbakanlık Basımevi.

Çakan, İ. L. (2006). Âkif̧̧e Tespistler-Değerlendirmeler, İstanbul.

Çantay, B. H. B. (1966). Âkifnâme (Mehmed Âkif), İstanbul: Ahmed Sait Matbası.

Çantay, H. B. (1964). Kara Günler ve İbret Levhaları, İstanbul: Ahmed Sait Matbası.

Çevik, Z. (2009). I. Meclis'te Bir Meb'us: Mehmet Akif (Ersoy) Bey, I. Uluslararası Mehmet Akif Ersoy Sempozyumu, Burdur, C. II, 855-867,.

Çevik, Z. (2010). Batı Anadolu'da Kuva-yı Milliyeci Bir Aydın: Hasan Basri Bey (Çantay) Bey, Kuva-yı Milliye'nin 90. Yılında İzmir ve Batı Anadolu" Uluslararası Sempozyum Bildirileri 6-8 Eylül 2009, II. Kitap, (ss.107-120), Ankara: İzmir Büyükşehir Belediyesi Yayını.

Çevik, Z. "I. Meclis Gizli Celse Zabıtlarına Göre Karesi Mebusu Hasan Basri (Çantay) Bey'in Siyasi Mücadelesi’nden Örnekler", Vefatının 50. Yılında Hasan Basri Çantay Sempozyumu", 19-21 Eylül 2014, (yayınlanmamış bildiri).

Çiçek, H. (2017). "Dostluğa Övgü: Cicero ve Mevlâna”, Yüzüncü Yll Üniversitesi Sosyal Bilimler Enstitüsü Dergisi, (1), Özel Sayı, 1-7.

Demirel, A. (2010). Illk Mesclis'in Vekilleri (Millî Mücadele Döneminde Seçimler), İstanbul: İletişim Yayınları.

Doğan, M. (1992). Büyük Türkçe Sözlük, Ankara: Rehber Yayınları.

Edip, E. 1357 (1938). Mehmet Âkif C.I, yer yok: Asarı İlmiye Kütüphanesi Neşriyatı.

Erişirgil, E. (1986). İslamcı Bir Şairin Romanı Mehmet Akif, Ankara: Türkiye İş Bankası Kültür Yayınları.

Esengin, K. (Emekli General). (1975). Millî Mücadelede İ̧ Ayaklanmalar, İstanbul: Ağrı Yayınları.

Goloğlu, M. (1971). Millî Mücadele Tarihi 4, Cumhuriyete Doğru (1921-1922), Ankara: Başnur Matbaasi.

Gülmez, N. (1999). Kurtuluş Savaşı'nda Anadolu'da Yeni Gün, Ankara: Atatürk Araştırma Merkezi Yayını. 
Işık, E. (1993). "Çantay: Hasan Basri”, TDV İslâm Ansiklopedisi, (8), 218-219, İstanbul: TDV yayınları.

İlgürel, M. (1999). Millî Mücadele'de Balıkesir Kongreleri, İstanbul: Atatürk Araştırma Merkezi Yayın1.

İmamoğlu, A. (2008). Mehmet Âkif'te Dostluk ve Dayanışma. Vefatının 71. yılında Mehmet Âkif Ersoy Bilgi Şöleni 2, Mehmet Âkif Dönemi ve Çevresi, Ankara: TYB Vakfı Mehmet Âkif Araştırmaları Merkezi Yayınları.

Kaplan, M. vd. (1981). Devrin Yazarlarının Kalemiyle Millî Mücadele ve Gazi Mustafa Kemal I, İstanbul: Kültür Bakanlığı Yayınları.

Karataş, T. (2009). Hasan Basri Çantay'ın Gözüyle Mehmet Âkif. Vefatının 72. yılında Mehmet Âkif Ersoy Bilgi Şöleni 3, Mehmet Âkif ve Edebî ve Fikrî Akımlar, Ankara: TYB Vakfı Mehmet Âkif Araştırmaları Merkezi Yayınları.

Kurtuluş Savaşı'na Yön Verenler: Cumhuriyet'in Kuruluşunun 70. Yıl Armağanı, (1994). Ankara: Gazi Üniversitesi Atatürk İlkeleri ve İnkilâp Tarihi Araştırma ve Uygulama Merkezi Yayın1.

Kutay, C. (ty). Türkiye İstiklâl ve Hürriyet Mücadeleleri Tarihi C. (1-20), İstanbul: Alioğlu Yayınevi.

Kutay, C. (1972). Kurtuluşun ve Cumhuriyetin Manevi Mimarları, Ankara: Diyanet İşleri Başkanlığı Yayınları.

Mısıroğlu, K. (1967). Kurtuluş Savaşında Sarıklı Mücahitler, İstanbul: Tan Gazetesi ve Matbaas1.

Moral1, N. (1973). Mütareke'de İzmir Olayları, Ankara.

Öztürk, İ. S. (2007). Türklügü̈n İdam Fermanı Sevr Antlaşması (Tam Metin 433 Madde Mondros ve Lozan Ekleriyle), Ankara.

Öztürk, N. (2009). M. Âkif'in İ̧̧erisinde İstiklâl Marşı'nı Yazdı̆̆ "Kasr-ı Ebniye"yi İnşa Ettiren Tâceddin Dergâhı Şeyhi Osman Vâfí Efendi. Vefatının 72. yılında Mehmet Âkif Ersoy Bilgi Şöleni 3, Mehmet Ấkif ve Edebî ve Fikrî Akımlar, Ankara: TYB Vakfi Mehmet Âkif Araştırmaları Merkezi Yayınları.

Pallis, A. A. (1997). Yunanlıların Anadolu Macerası (1915-1922), (Azizoğlu, O. Çev.) İstanbul: Yap1 Kredi Yayınları.

Parlak, T. (1982). İşgalden Kurtuluşa "1" Yunan Ege'ye Nasıl Geldi "İlk Günler", İzmir: İzmir Sosyal Hizmetler Vakfi Kültür Yayını.

Peker, N. (1955). 1918-1923 İstiklâl Savaşının Vesika ve Resimleri, İnebolu ve Kastamonu Havalisi, İstanbul.

Sarıkoyuncu, A. (2002). Millî Mücadelede Din Adamları I-II, Ankara.

Selek, S. (1966). Anadolu İhtilâli, İstanbul: Burçak Yayınevi.

Şen, A. (ty). Bir Destan Adam Mehmet Âkif Ersoy, İstanbul: Numune Matbaacılık ve Cilt Sanayi.

Tansel, S. (1973). Mondros'tan Mudanya'ya I, Ankara: Başbakanlık Basımevi.

Uğur, M. (1994). Hasan Basri Çantay, Ankara: Türkiye Diyanet Vakfı Yayınları.

Uzunçarş111, İ. H. (2000). Karesi Vilâyeti Tarihçesi, Balıkesir: Zağnos Kültür ve Eğitim Vakfı Yayını. 
Vakkasoğlu, V. (1987). Osmanlıdan Cumhuriyete İslâm Alimleri, İstanbul: Yaylacık Matbaası.

Yazıc1, N. (1993). "Hasan Basri (Çantay) ve Ses Gazetesi", Ankara Üniversitesi Türk İnkilap Tarihi Enstitüsü Atatürk Yolu Dergisi, Y11 6, 12(3), 431-445.

\section{ETIK ve BILIMSEL İLKELER SORUMLULUK BEYANI}

$\mathrm{Bu}$ çalışmanın tüm hazırlanma süreçlerinde etik kurallara ve bilimsel atıf gösterme ilkelerine riayet edildiğini yazar(lar) beyan eder. Aksi bir durumun tespiti halinde Afyon Kocatepe Üniversitesi Sosyal Bilimler Dergisi'nin hiçbir sorumluluğu olmayıp, tüm sorumluluk makale yazarlarına aittir. 